\title{
A 1-year characterization of organic aerosol composition and sources using an extractive electrospray ionization time-of-flight mass spectrometer (EESI-TOF)
}

\author{
Lu Qi $^{1,2}$, Alexander L. Vogel ${ }^{1, a}$, Sepideh Esmaeilirad ${ }^{1}$, Liming Cao $^{3}$, Jing Zheng ${ }^{4}$, Jean-Luc Jaffrezo ${ }^{5}$, Paola Fermo ${ }^{6}$ \\ Anne Kasper-Giebl ${ }^{7}$, Kaspar R. Daellenbach ${ }^{1, b}$, Mindong Chen $^{2}$, Xinlei Ge ${ }^{2}$, Urs Baltensperger ${ }^{1}$, André S. H. Prévôt ${ }^{1}$, \\ and Jay G. Slowik ${ }^{1}$ \\ ${ }^{1}$ Laboratory of Atmospheric Chemistry, Paul Scherrer Institute (PSI), 5232 Villigen, Switzerland \\ ${ }^{2}$ Collaborative Innovation Center of Atmospheric Environment and Equipment Technology, \\ Nanjing University of Information Science \& Technology, Nanjing, 210044, China \\ ${ }^{3}$ Key Laboratory for Urban Habitat Environmental Science and Technology, School of Environment and Energy, \\ Peking University Shenzhen Graduate School, Shenzhen, 518055, China \\ ${ }^{4}$ State Key Joint Laboratory of Environmental Simulation and Pollution Control, College of Environmental Sciences \\ and Engineering, Peking University, Beijing, 100871, China \\ ${ }^{5}$ University Grenoble Alpes, CNRS, IGE, 38000 Grenoble, France \\ ${ }^{6}$ Department of Chemistry, University of Milan, 20133 Milan, Italy \\ ${ }^{7}$ Institute of Chemical Technologies and Analytics, Vienna University of Technology, 1060 Vienna, Austria \\ ${ }^{a}$ now at: Institute for Atmospheric and Environmental Sciences, Goethe University, Frankfurt am Main, Germany \\ bnow at: Institute for Atmospheric and Earth System Research, University of Helsinki, Helsinki, Finland
}

Correspondence: Jay G. Slowik (jay.slowik@psi.ch) and André S. H. Prévôt (andre.prevot@psi.ch)

Received: 18 December 2019 - Discussion started: 10 January 2020

Revised: 17 May 2020 - Accepted: 8 June 2020 - Published: 8 July 2020

\begin{abstract}
The aerosol mass spectrometer (AMS), combined with statistical methods such as positive matrix factorization (PMF), has greatly advanced the quantification of primary organic aerosol (POA) sources and total secondary organic aerosol (SOA) mass. However, the use of thermal vaporization and electron ionization yields extensive thermal decomposition and ionization-induced fragmentation, which limit chemical information needed for SOA source apportionment. The recently developed extractive electrospray ionization time-of-flight mass spectrometer (EESI-TOF) provides mass spectra of the organic aerosol fraction with a linear response to mass and no thermal decomposition or ionization-induced fragmentation. However, the costs and operational requirements of online instruments make their use impractical for long-term or spatially dense monitoring applications. This challenge was overcome for AMS measurements by measuring re-nebulized water extracts from ambient filter samples. Here, we apply the same strategy
\end{abstract}

for EESI-TOF measurements of 1 year of $24 \mathrm{~h}$ filter samples collected approximately every fourth day throughout 2013 at an urban site. The nebulized water extracts were measured simultaneously with an AMS. The application of positive matrix factorization (PMF) to EESI-TOF spectra resolved seven factors, which describe water-soluble OA: less and more aged biomass burning aerosol $\left(\mathrm{LABB}_{\mathrm{EESI}}\right.$ and $\mathrm{MABB}_{\mathrm{EESI}}$, respectively), cigarette-smoke-related organic aerosol, primary biological organic aerosol, biogenic secondary organic aerosol, and a summer mixed oxygenated organic aerosol factor. Seasonal trends and relative contributions of the EESI-TOF OA sources were compared with AMS source apportionment factors, measured water-soluble ions, cellulose, and meteorological data. Cluster analysis was utilized to identify key factor-specific ions based on PMF. Both LABB and MABB contribute strongly during winter. LABB is distinguished by very high signals from $\mathrm{C}_{6} \mathrm{H}_{10} \mathrm{O}_{5}$ (levoglucosan and isomers) and $\mathrm{C}_{8} \mathrm{H}_{12} \mathrm{O}_{6}$, whereas MABB is 
characterized by a large number of $\mathrm{C}_{x} \mathrm{H}_{y} \mathrm{O}_{z}$ and $\mathrm{C}_{x} \mathrm{H}_{y} \mathrm{O}_{z} \mathrm{~N}$ species of two distinct populations: one with low $\mathrm{H}: \mathrm{C}$ and high $\mathrm{O}: \mathrm{C}$ and the other with high $\mathrm{H}: \mathrm{C}$ and low $\mathrm{O}: \mathrm{C}$. Two oxygenated summertime SOA sources were attributed to terpene-derived biogenic SOA, a major summertime aerosol source in central Europe. Furthermore, a primary biological organic aerosol factor was identified, which was dominated by plant-derived fatty acids and correlated with free cellulose. The cigarette-smoke-related factor contained a high contribution of nicotine and high abundance of organic nitrate ions with low $m / z$.

\section{Introduction}

Organic aerosol (OA) has significant but highly uncertain effects on climate and human health (Heal et al., 2012; Kelly et al., 2012). OA is either directly emitted (primary organic aerosol, POA) or formed in the atmosphere by gasphase oxidation of anthropogenic and natural volatile organic compounds, followed by condensation or nucleation of less volatile products (secondary organic aerosol, SOA). The Aerodyne aerosol mass spectrometer (AMS) provides online measurements of OA composition and in combination with statistical methods such as positive matrix factorization (PMF) has greatly advanced the quantification of primary organic aerosol (POA) sources and total secondary organic aerosol (SOA) mass, although individual SOA sources are not typically separable (Jimenez et al., 2003; DeCarlo et al., 2008; Lanz et al., 2007; Ulbrich et al., 2009; Crippa et al., 2013a; Elser et al., 2016; Zhang et al., 2011). However, the AMS cost and operational requirements make its use impractical for long-term or spatially dense monitoring applications. A few solutions were developed to overcome these shortcomings; e.g., the robust, less expensive, Aerosol Chemical Speciation Monitor (ACSM, Ng et al., 2007) and the Time-of-Flight (TOF)-ACSM were developed for longterm campaigns (Fröhlich et al., 2013, 2015); however, the low mass resolution of these instruments reduces their utility. Traditional offline techniques like gas chromatographymass spectrometry (GC-MS) or liquid chromatographymass spectrometry (LC-MS) are chemically highly specific but measure only a fraction the total organic aerosol. Another solution to this problem is the application of online instrumentation to extracted and re-aerosolized material from particle filter samples routinely collected at ambient monitoring stations (Daellenbach et al., 2016). Compared to online measurements, there are a few advantages: (1) the practicality of long-term measurements; (2) the practicality of making simultaneous measurements across multiple sites (possibly including sites where access or infrastructure restrictions make the deployment of high-end instrumentation challenging); (3) that such multi-site measurements can be performed with not only the same instrument type but even a single in- strument, improving comparability; (4) the capability of particle composition measurement outside the size-dependent transmission range of the measuring instrument (e.g., coarsemode particles in the AMS); (5) and that the expense of additional sample analysis by newly developed instruments is low once the filter sampling infrastructure is installed. On the other hand, drawbacks of the filter sampling and offline measurement strategy include possible positive or negative artifacts due to condensation or evaporation of semi-volatile organics or aging during sampling, while compound-dependent extraction efficiencies make quantification more challenging.

The general analytical strategy outlined above, specifically the application of online instrumentation capable of highly time-resolved measurements to offline analysis of collected samples, has two key advantages relative to traditional offline techniques. First, the entire OA fraction can be analyzed in comparison to the extracted one for the offline analysis (64\%-76\% in the case of Switzerland, Daellenbach et al., 2016). Second, sources that are tightly correlated on the $24 \mathrm{~h}$ timescales typical of filter measurement techniques may be more easily resolved at higher time resolution; real-world source profiles from online measurements can therefore be used in advanced factor analysis of offline techniques to improve source separation (Daellenbach et al., 2016; Bozzetti et al., 2017).

While the offline AMS technique has proven successful in characterizing POA sources and SOA mass, the AMS chemical resolution is limited by substantial thermal decomposition and ionization-induced fragmentation of the analyte molecules. This problem is especially severe for the highly oxygenated, multifunctional molecules prevalent in SOA, and, in most cases, prevents identification of sourcespecific SOA factors. In contrast, the recently developed extractive electrospray ionization time-of-flight mass spectrometer (EESI-TOF) is capable of online measurements at high time resolution without thermal decomposition or ionizationinduced fragmentation (Lopez-Hilfiker et al., 2019). The EESI-TOF has been successfully deployed in several laboratory (Pospisilova et al., 2020) and field (Qi et al., 2019; Stefenelli et al., 2019) campaigns. It yields signals that are linear with mass (albeit with ion-dependent response factors), making it suitable for source apportionment.

Here we present the first offline EESI-TOF source apportionment analysis, conducted on 1 year of $\mathrm{PM}_{10}$ filter samples collected in Zurich, Switzerland, and complemented by AMS measurements. This analysis describes the sources and processes governing the water-soluble fraction of OA. The chosen site is very well characterized, with multiple source apportionment studies by online measurements with an AMS in different seasons (Lanz et al. 2010), an Aerosol Chemical Speciation Monitor (ACSM) during a full year (Canonaco et al., 2013, 2015), and an EESI-TOF during summer and winter (Qi et al., 2019; Stefenelli et al., 2019), as well as offline measurements with an AMS and ${ }^{14} \mathrm{C}$ analyses (Daellenbach et al., 2016, 2017; Zotter et al., 2014). 


\section{Methods}

\subsection{Site description and sample collection}

Sampling was conducted at the NABEL station in Zurich $\left(47^{\circ} 22^{\prime} \mathrm{N}, 8^{\circ} 33^{\prime} \mathrm{E}\right)$, described in detail elsewhere (Canonaco et al., 2013; Lanz et al., 2007). Briefly, this station is an urban location, situated in the Kaserne Park in the city center. In addition to sources characteristic of urban areas, local influences from nearby restaurants, traffic, and human activities (e.g., cigarette smoking) are sometimes observed (Qi et al., 2019; Stefenelli et al., 2019). Meteorological parameters, including temperature, relative humidity $(\mathrm{RH})$, wind speed (WS), wind direction (WD), and global radiation, as well as concentrations of gas-phase species, including sulfur dioxide $\left(\mathrm{SO}_{2}\right)$, nitrogen dioxide $\left(\mathrm{NO}_{2}\right)$, and nitrogen oxide $(\mathrm{NO})$, are recorded by the monitoring station.

$\mathrm{PM}_{10}$ samples (91 filters) were collected every fourth day for $24 \mathrm{~h}$ throughout the year 2013 on quartz fiber filters (14.7 $\mathrm{cm}$ diameter) using high-volume samplers (Digitel DHA80, 500 $\mathrm{L} \mathrm{min}^{-1}$ ). Before sampling, the filters were prebaked at $800^{\circ} \mathrm{C}$ for $8 \mathrm{~h}$. After collection, filters were wrapped in aluminum foil or lint-free paper, sealed in polyethylene bags, and stored at $-20^{\circ} \mathrm{C}$. Field blanks were collected and stored following the same procedure (Bozzetti et al., 2017; Daellenbach et al., 2017).

\subsection{Offline measurements}

The filters used for the present analysis were investigated by offline AMS PMF in a previous study (Daellenbach et al., 2017). Here, to optimize comparison between the offline AMS and offline EESI-TOF techniques, we produced a new aerosol extract, which was then nebulized for new simultaneous AMS and EESI-TOF measurements. In this way, we avoided differences due to extraction or nebulizer performance, filter aging during storage, system background or contamination, handling artifacts, etc., which might occur if the current EESI-TOF analyses were to be compared with the original offline AMS study. As a consequence, the AMS dataset presented here is not completely identical to that of Daellenbach et al. (2017), although the observed differences are small.

For each analyzed filter sample, one $16 \mathrm{~mm}$ diameter filter punch was subjected to ultrasonic extraction in $10 \mathrm{~mL}$ of ultrapure water $\left(18.2 \mathrm{M} \Omega \mathrm{cm}\right.$ at $25^{\circ} \mathrm{C}$, total organic carbon (TOC) $<3 \mathrm{ppb}$ ) for $20 \mathrm{~min}$ at $30^{\circ} \mathrm{C}$. The extracted liquid was then filtered with $0.22 \mu \mathrm{m}$ nylon membrane syringe filters and nebulized in synthetic air ( $80 \%$ volume $\mathrm{N}_{2}, 20 \%$ volume $\mathrm{O}_{2}$; Carbagas, 3073 Gümligen, Switzerland) using a customized Apex Q nebulizer (Elemental Scientific Inc., Omaha, USA) operating at $60^{\circ} \mathrm{C}$. The resulting droplets were dried using a Nafion dryer and then analyzed by an extractive electrospray ionization time-of-flight mass spectrometer (EESI-TOF) and a high-resolution time-of-flight AMS
(HR-ToF-AMS). The total measurement time of each sample was 5 min. Before and after each sample, a measurement blank was generated by sampling nebulized ultrapure water for $10 \mathrm{~min}$. Field blanks were measured following the same extraction procedure as the collected filter samples, yielding a signal not statistically different from that of nebulized ultrapure water. Each blank sample was recorded for $480 \mathrm{~s}$.

\subsubsection{Offline AMS analysis}

The offline AMS analysis followed the methodology developed by Daellenbach et al. (2016). The offline AMS operation was similar to other AMS measurements (Hu et al., 2013; DeCarlo et al., 2006). HR-TOF-AMS data were processed using the software SQUIRREL (SeQUential Igor data RetRiEvaL; D. Sueper, University of Colorado, Boulder, CO, USA) v.1.57 and PIKA (Peak Integration by Key Analysis) v.1.16 for the IGOR Pro software package (Wavemetrics, Inc., Portland, OR, USA). The high-resolution mass spectral analysis was performed for each $\mathrm{m} / z$ (mass to charge) in the range of 12-120 at AMS V mode and yielded a dataset consisting of 257 ions (excluding isotopes and $\mathrm{CO}_{2}$-dependent ions). The interference of $\mathrm{NH}_{4} \mathrm{NO}_{3}$ on the $\mathrm{CO}_{2}^{+}$signal was corrected (Pieber et al., 2016) as follows:

$$
\begin{aligned}
\mathrm{CO}_{2, \text { real }} & =\mathrm{CO}_{2, \text { meas }}-\left(\frac{\mathrm{CO}_{2, \text { meas }}}{\mathrm{NO}_{3, \text { meas }}}\right)_{\mathrm{NH}_{4} \mathrm{NO}_{3} \text {,pure }} \\
& \cdot \mathrm{NO}_{3, \text { real }},
\end{aligned}
$$

where the $\left(\frac{\mathrm{CO}_{2} \text {,meas }}{\mathrm{NO}_{3} \text {, meas }}\right)_{\mathrm{NH}_{4} \mathrm{NO}_{3} \text {, pure }}$ correction factor was determined based on the measurement period and varied between $1 \%$ and $\sim 5 \%$.

The AMS data were rescaled to the ambient concentration by normalizing the measured signal to the estimated watersoluble organic matter (WSOM) concentration, which was calculated as the product of the measured water-soluble organic carbon (WSOC) multiplied by the OM : OC ratios determined from the offline AMS results. This method and the associated uncertainties are described in detail by Daellenbach et al. $(2016,2017)$. Note that because we do not attempt to correct for the water extraction efficiency of OM components, the analysis presented herein describes the source apportionment of AMS WSOM.

\subsubsection{Extractive Electrospray Ionization Time-of-flight Mass Spectrometer (EESI-TOF)}

The EESI-TOF is discussed in detail elsewhere (LopezHilfiker et al., 2019; Qi et al., 2019), and a brief overview is presented here. Aerosol particles are continuously sampled through a $6 \mathrm{~mm}$ outer diameter (OD), $5 \mathrm{~cm}$ long multichannel extruded carbon denuder housed in a stainless steel tube. The particle flow intersects a spray of charged droplets generated by a conventional electrospray capillary. Particles collide with the electrospray droplets and the soluble com- 
ponents are extracted. The droplets are evaporated gently, yielding ions that are detected by the TOF-MS. The electrospray working solution is a $50: 50$ water: methanol $(\mathrm{MeOH}$, UHPLC-MS, LiChrosolv) mixture with $100 \mathrm{ppm} \mathrm{NaI} \mathrm{(99 \% ,}$ Sigma-Aldrich) as a charge carrier. Organic components are detected as adducts with $\mathrm{Na}^{+}$. Spectra are recorded in positive ion mode at $5 \mathrm{~s}$ time resolution. In normal operation, the EESI-TOF alternates between direct sampling of aerosol and sampling through a particle filter to provide a background measurement; however, the filter was not used in this study. Instead, the measurement blanks (nebulized ultrapure water) were used to determine the background. The EESI-TOF data were processed in Tofware 2.5.7 (Tofwerk AG, Thun, Switzerland).

We report the signal measured by the EESI-TOF in terms of mass flux of ions to the microchannel plate detector $\left(\mathrm{ag} \mathrm{s}^{-1}\right.$, neglecting the mass of $\left.\mathrm{Na}^{+}\right)$, calculated as shown in Eq. (2).

$M_{x}=I_{x} \cdot\left(\mathrm{MW}_{x}-\mathrm{MW}_{\mathrm{cc}}\right)$

Here $M_{x}$ is the mass flux of ions in units of attograms per second, where $x$ represents the measured molecular ion. $I_{x}$ is the recorded signal measured by EESI-TOF. MW $x$ and $\mathrm{MW}_{\mathrm{cc}}$ represent the molecular weight of the ion and the charge carrier (e.g., $\mathrm{Na}^{+}, \mathrm{H}^{+}$), respectively. Note that this measured mass flux can in principle be related to the ambient OA concentration by the instrument flow rate, EESI extraction and ionization efficiency, declustering probability, and ion transmission, where several of these parameters are ion-dependent and currently unknown (Lopez-Hilfiker et al., 2019). The EESI-TOF data were normalized to WSOC by using the AMS OM: OC ratios mentioned above. Similar to the AMS, no corrections for the efficiency of the water extraction from the filter samples is applied, and the offline EESI-TOF analysis therefore strictly relates only to the WSOM fraction. Note that because online EESI-TOF operation already requires extraction into the spray droplets $(1: 1$ water: acetonitrile mixture), major differences between the measured OA fraction between online and offline analyses are unlikely. A comparison of the EESI-TOF to the AMS signal in terms of total signal or mass, bulk properties, and source apportionment results is presented in Sect. 3.4.

\subsubsection{Other offline measurements}

Filters were analyzed for organic and elemental carbon (OC, EC) using a thermo-optical transmission method with a Sunset OC-EC analyzer, following the EUSAAR-2 thermaloptical transmission protocol (Cavalli et al., 2010). Watersoluble organic carbon was measured using a total organic carbon analyzer with water extraction followed by catalytic oxidation and nondispersive infrared detection of $\mathrm{CO}_{2}$. Water-soluble major ions $\left(\mathrm{K}^{+}, \mathrm{Na}^{+}, \mathrm{Mg}^{2+}, \mathrm{Ca}^{2+}, \mathrm{NH}_{4}^{+}\right.$, $\mathrm{SO}_{4}^{2-}, \mathrm{NO}_{3}^{-}$, and $\mathrm{Cl}^{-}$) and methane sulfonic acid were determined using ion chromatography (Cuccia et al., 2013).
Levoglucosan measurements (Piazzalunga et al., 2013) were performed with a high-performance anion exchange chromatographer (HPAEC) with pulsed amperometric detection (PAD) using an ion chromatograph (Dionex ICS-1000). Free cellulose was determined using an enzymatic conversion to d-glucose and subsequent determination of glucose with an HPAEC.

\subsection{Source apportionment techniques}

The EESI-TOF PMF input data matrices included 91 filter samples. The input errors $\sigma_{i j}$ were calculated as the uncertainty related to ion counting statistics and ion-to-ion signal variability at the detector $\left(\delta_{i, j}\right)$, which were added in quadrature to the blank variability background $\left(\beta_{i j}\right)$ (Qi et al., 2019).

$\sigma_{i j}=\sqrt{\delta_{i j}^{2}+\beta_{i j}^{2}}$

We applied a minimum error corresponding to the measurement of a single ion during the $5 \mathrm{~s}$ averaging period. Variables with a low signal-to-noise ratio $(\mathrm{SNR}<0.2)$ were removed, whereas "weak" variables $(0.2<\mathrm{SNR}<2)$ were down-weighted by a factor of 3 rather than 2 (following the recommendations of Paatero and Hopke, 2009). In total, 1070 fitted ions (1068 adducts with $\mathrm{Na}^{+}$and 2 with $\mathrm{H}^{+}$) between $\mathrm{m} / z 135$ and 400 were identified.

The PMF source apportionment technique requires the time series of ions from high-resolution mass spectral fitting, along with their corresponding uncertainties, as input. As for the EESI-TOF, the input AMS errors for PMF were calculated as the sum in quadrature of the AMS instrument uncertainties (including ion-counting statistics and ion-to-ion signal variability at the detector $\left.\left(\delta_{i, j}\right)\right)$ and the blank variability $\left(\beta_{i j}\right)$ (Ulbrich et al., 2009).

The offline EESI-TOF and offline AMS source apportionment was performed using positive matrix factorization (PMF) (Paatero and Tapper, 1994) as implemented by the Multilinear Engine (ME-2) and with model configuration and analysis executed via the SoFi (Source Finder, version 6.39) interface (Canonaco et al., 2013). PMF is a linear statistical model to describe the variability of a multivariate dataset. Specifically, an input data matrix (with elements $x_{i, j}$, where the $i$ and $j$ indices denote time and $m / z$, respectively) is described as the linear combination of a set of static factor profiles ( $f_{i, k}$, where the $k$ index denotes discrete factors) and temporal variation $\left(g_{k, j}\right)$, as shown in Eq. (4):

$x_{i, j}=\sum_{z=1}^{p}\left(f_{i, k} \cdot g_{k, j}\right)+e_{i, j}$.

Here, $e_{i, j}$ represents elements of the residual matrix and $p$ is the total number of factors. The PMF algorithm iteratively solves Eq. (4) by minimizing the objective function $Q$, defined in Eq. (5) as follows:

$\mathrm{Q}=\sum_{i} \sum_{j}\left(\frac{e_{i j}}{\sigma_{i j}}\right)^{2}$ 
where $\sigma_{i, j}$ represents entries in the input uncertainty matrix.

The ME-2 implementation of the PMF algorithm offers an efficient exploration of the solution space by allowing the model to be directed towards environmentally meaningful rotations. Here this was done by constraining the factor profile elements $f_{i, k}$ for one or more factors (Canonaco et al., 2013), implemented using the $a$ value method, where the output $f_{i, k}$ for each constrained factor is required to satisfy Eq. (6):

$f_{i, k}=f_{i, k}^{\prime} \pm a \cdot f_{i, k}^{\prime}$.

Here, $f_{i, k}^{\prime}$ represents a predetermined anchor profile and the scalar $a(0 \leq a \leq 1)$ determines the tightness of constraint. Anchor profiles may be obtained by several methods, including prior studies, laboratory measurements of known sources, or analysis of a subset of the current dataset, and are discussed on a case-by-case basis in Sect. 3.1 (AMS) and 3.2 (EESI-TOF) (Canonaco et al., 2015).

\subsection{Identification of source-specific ions}

To determine ions characteristic of individual factors (or groups of related factors), agglomerative hierarchical clustering was conducted on the EESI-TOF matrix of PMF profiles. A dendrogram is used to show relationships between members of a group. A more detailed description is found in Qi et al. (2019).

Here, we summarize the steps as follows: (1) calculation of the standardized value ( $z$ score) is performed along the ions by using Eq. (7):

$z=\frac{x-\mu}{\sigma}$.

The $\mu$ is the mean value, $\sigma$ is the standard deviation, and $Z$ represents the distance between the raw score and the mean value in units of the standard deviation. (2) Formation of groups of the new calculated data is performed by using the Euclidean distance (Eq. 8):

$\sigma \operatorname{dist}\left(x_{i}, x_{j}\right)=\sqrt{\sum_{m=1}^{n}\left(\frac{x_{i m}-x_{j m}}{\sigma_{m}}\right)^{2}}$.

Here, $i=(1, \ldots, m)$ and $j=(1, \ldots, m)$, (3) clustering is performed along the columns (producing row-clustered groups of factors) and along the rows (producing the clustered ions to each group). The calculation and the generation of the dendrogram were performed with MATLAB R2017b (Qi et al., 2019).

\section{Results and discussions}

\subsection{Interpretation of AMS-PMF factors}

Here we summarize the results of the AMS-PMF analysis on the WSOM fraction, comprising comprised $58 \%$ of the total OM, which as noted in Sect. 2.2 are very similar to those of Daellenbach et al. (2017) conducted on different extracts from the same ambient filter samples. $\mathrm{HOA}_{\mathrm{AMS}}$ and $\mathrm{COA}_{\mathrm{AMS}}$ mass profiles were constrained using anchor profiles obtained from winter in Paris (Crippa et al., 2013b) with $a$ values of 0.1 and 0.2 , respectively. A six-factor solution was selected as the best representation for the AMS PMF analysis, yielding factors identified as hydrocarbonlike OA ( $\left.\mathrm{HOA}_{\mathrm{AMS}}\right)$, cooking OA $\left(\mathrm{COA}_{\mathrm{AMS}}\right)$, biomass burning $\mathrm{OA}\left(\mathrm{BBOA}_{\mathrm{AMS}}\right)$, winter oxygenated $\mathrm{OA}\left(\mathrm{WOOA}_{\mathrm{AMS}}\right)$, summer oxygenated OA (AMS), and sulfur-containing OA $\left(\mathrm{SCOA}_{\mathrm{AMS}}\right)$. The methods of factor classification and factor selection for the AMS PMF results are similar to Daellenbach et al. (2017), although a detailed sensitivity analysis was not repeated. Figures 1 and S1 in the Supplement show the mass spectra and the time series of the AMS factors, respectively. The main characteristics of the AMS PMF factors are summarized below. $\mathrm{BBOA}_{\mathrm{AMS}}$ exhibits high contributions from $\mathrm{C}_{2} \mathrm{H}_{4} \mathrm{O}_{2}^{+}(\mathrm{m} / z \mathrm{z})$, a characteristic ion from the fragmentation of anhydrosugars such as levoglucosan (Sun et al., 2013; Takahama et al., 2013; Lin et al., 2016). The BBOA AMs time series shows the expected seasonal variation with elevated concentrations in winter, supporting the identification of this factor. The oxygenated OA factors are resolved based on the differences in their seasonal behavior: $\mathrm{SOOA}_{\mathrm{AMS}}$ (elevated in summer) and $\mathrm{WOOA}_{\mathrm{AMS}}$ (elevated in winter). This season-based separation of OOA factors is typical of offline AMS analysis (Bozzetti et al., 2016; Daellenbach et al., 2017) but contrasts with typical results from PMF analysis of highly time-resolved data from short-term measurements, where OOA factors are more likely to be separated by volatility and/or photochemical age (Zhang et al., 2011; Jimenez et al., 2009). Even though AMs has a high contribution in summer and shows an increase with rising temperature, it also contributes, to a lesser degree, during the other seasons (Fig. S1, Daellenbach et al., 2017). The mass spectrum of $\mathrm{SCOA}_{\mathrm{AMS}}$ is dominated by the fragment $\mathrm{CH}_{3} \mathrm{SO}_{2}^{+}$, which was found to derive from a sulfur-containing compound other than methanesulfonic acid (MSA) (Daellenbach et al., 2017). This factor is believed to derive from primary traffic-related sources, and in sizeresolved analyses at other sites it has been found mainly in the coarse mode (Vlachou et al., 2018). The meteorological data, ion data, and the factor comparison between EESI-TOF and AMS are presented in Sect. 3.2.2. 


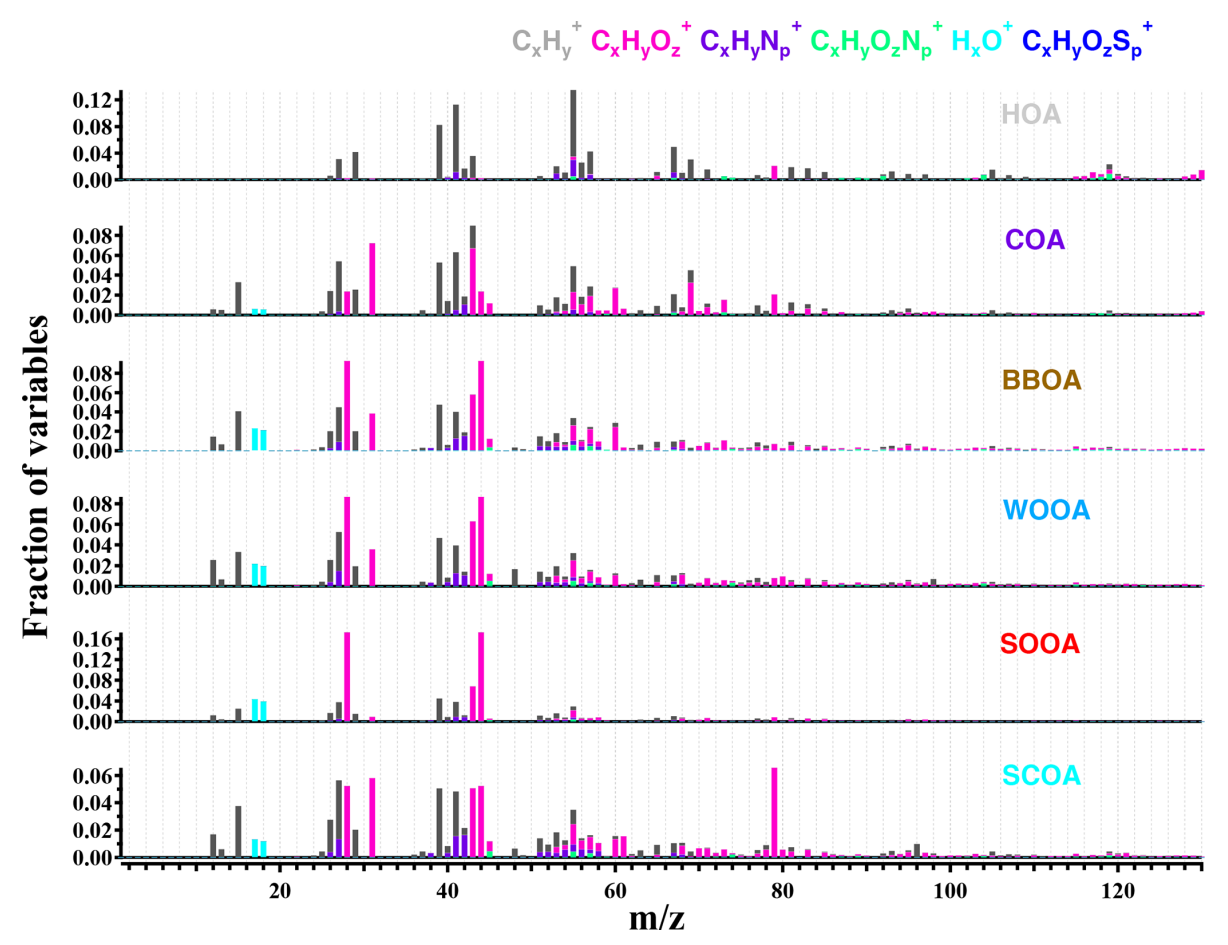

Figure 1. Factor profiles for the six-factor solution for AMS results with $\mathrm{HOA}_{\mathrm{AMS}}$ and COA AMS constrained by $a=0.1$. The total signal of each factor is normalized to unity, and the $y$ axis presents the fractional contributions of the variables to the total signal of the fac-

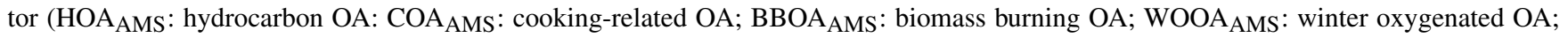
SOOA $_{\mathrm{AMS}}$ : summer oxygenated OA; $\mathrm{SCOA}_{\mathrm{AMS}}$, sulfur-containing oxygenated $\mathrm{OA}$ ).

\subsection{EESI-TOF source apportionment}

\subsubsection{EESI-TOF solution selection}

Selection of an appropriate number of factors is a critical component of any PMF analysis. Increasing the number of factors gives the model more freedom to explain subtle variations in the data, but too many factors may force the model to split a physically meaningful factor into nonmeaningful ones. In this section, we present how we selected the number of PMF factors based on the residual analysis and the solution interpretability. The offline EESI-TOF PMF analysis was performed for solutions with 1 to 10 factors. Solutions were assessed based on the internal consistency of the factor mass spectra, and comparison of factor time series with offline AMS PMF solutions, external tracers, and auxiliary data. The $Q$ normalized by its expected value ( $\left.Q / Q_{\text {exp }}\right)$ between the various runs was around 2.4 for the six-factor solution and higher (Fig. S2). Here we present a brief overview of the retrieved solutions as a function of the number of factors. Characteristics of the factors, including justifications for their assigned labels, are presented in Sect. 3.2.2.

The five-factor solution is largely driven by differences between the winter and summer seasons (Fig. S3). The solution includes two factors related to biomass combustion. A less aged biomass burning ( $\mathrm{LABB}_{\mathrm{EESI}}$ ) factor, dominated by the ion $m / z 185.04\left(\mathrm{C}_{6} \mathrm{H}_{10} \mathrm{O}_{5} \mathrm{Na}^{+}, \mathrm{C}_{6} \mathrm{H}_{10} \mathrm{O}_{5}\right.$, levoglucosan, and its isomers). In the following text, the neutral formula is used to represent ions and exhibits high contributions over the last few months of the year, while a more aged biomass burning $\left(\mathrm{MABB}_{\mathrm{EESI}}\right)$ is elevated during both winters. These two factors are distinguished by their mass spectra, as discussed further in Sect. 3.2.2. A biogenic secondary organic aerosol $\left(\mathrm{BSOA}_{\mathrm{EESI}}\right)$ factor contributes during the warm season and has a negligible contribution from $\mathrm{C}_{6} \mathrm{H}_{10} \mathrm{O}_{5}$. The primary biological organic aerosol (PBOA $\mathrm{EESI}_{1}$ ) factor has a different time series that has no correlation with other external tracers. The last factor seems to be mixed due to the two major peaks at $m / z 163.12$ and $m / z$ 185.04. Based on the unique ion of $\mathrm{m} / z 163.12$ in the factor mass spectrum, which is tentatively explained by nicotine $\left(\mathrm{C}_{10} \mathrm{H}_{15} \mathrm{~N}_{2}^{+}\right)$, we denote it here as the "163.12" factor.

In the six-factor solution (Fig. S4), the LABB EESI, $_{\text {, }}$ $\mathrm{MABB}_{\mathrm{EESI}}, \mathrm{BSOA}_{\mathrm{EESI}}$, and $\mathrm{PBOA}_{\mathrm{EESI}}$ factors are qualitatively similar to their counterparts in the five-factor solution. However, the "163.12" factor is separated into a cigarettesmoke-related OA (CS-OA $A_{\mathrm{EESI}}$ ) factor retaining the prominent peak at 163.12 and a less aged biomass burning factor (LABB2 ${ }_{\text {EESI }}$ ) with a strong contribution from $\mathrm{C}_{6} \mathrm{H}_{10} \mathrm{O}_{5}$ and a high correlation with $\mathrm{BBOA}_{\mathrm{AMS}}$.

Increasing the number of factors to seven yields an additional factor, described as summer oxygenated organic 
aerosol (SMOAEESI), which exhibits a high peak in summer but also has a significant contribution throughout the year (Fig. 2). The time series correlates with AMS, and the profile is similar to that of photochemically generated, biogenicdominated SOA identified from online measurements at the same site (Stefenelli et al., 2019), as discussed in Sect. 3.2.2. As discussed in Sect. 3.3, SOAAEESI evidences a more regional and mixed composition than BSOAEESI.

When eight factors are assumed, the profile of the new factor points to an additional more aged biomass burning factor (MABB2 ${ }_{\text {EESI }}$ ) (Fig. S5) with two high peaks at $m / z 165.09$ $\left(\mathrm{C}_{7} \mathrm{H}_{13} \mathrm{NO}_{2}\right)$ and $m / z 185.04\left(\mathrm{C}_{6} \mathrm{H}_{10} \mathrm{O}_{5}\right)$. Adding this factor alters the time series of other factors, decreasing their correlation with relevant tracer. Further, its time series has no clear seasonal trend or correlation with other reference, so it does not provide further source information and is therefore disregarded. Increasing the number of factors beyond 8 yielded additional split or mixed factors without adding any new interpretable factors. We therefore selected the seven-factor solution for the analysis below.

\subsubsection{Overview of EESI-TOF source apportionment}

An overview of the EESI-TOF source apportionment analysis is presented in this section, with the factors discussed in detail in Sect. 3.3. Figure 2a shows the time series of the seven EESI-TOF PMF factors $\left(\mathrm{LABB} 1_{\mathrm{EESI}}, \mathrm{LABB} 2_{\mathrm{EESI}}, \mathrm{CS}-\mathrm{OA} \mathrm{EESI}_{\mathrm{E}}, \mathrm{PBOA}_{\mathrm{EESI}}\right.$, $\mathrm{MABB}_{\mathrm{EESI}}$, BSOA $\mathrm{EESI}_{\mathrm{E}}, \mathrm{SMOA}_{\mathrm{EESI}}$ ) over the entire year, together with relevant AMS PMF factors, meteorological conditions, and other ancillary measurements. The retrieved factors are analyzed in terms of their composition, correlation with markers, and relationship to offline AMS factors retrieved over the same period. Figure $2 \mathrm{~b}$ presents the factor mass spectra, with ions colored by number of nitrogen. Figure 3 presents the spectra as stacked histograms according to the chemical family, binned by the number of carbon atoms, with the vertical axis representing the relative signal intensity. We define three chemical families: $\mathrm{C}_{x} \mathrm{H}_{y} \mathrm{~N}_{z} \mathrm{O}_{\mathrm{k}}$, $\mathrm{C}_{x} \mathrm{H}_{y} \mathrm{~N}_{z}$, and $\mathrm{C}_{x} \mathrm{H}_{y} \mathrm{O}_{z}$, with the latter further separated into five groups by atomic $\mathrm{H}: \mathrm{C}$ ratios: $\mathrm{H}: \mathrm{C}<1.1,1.1-1.3,1.3-$ $1.5,1.5-1.7$, and $>1.7$.

As evidenced from the previous section and Figs. 2 and 3, many of the dominant ions in the EESI-TOF PMF analysis are shared by multiple factors. Here, we utilize a cluster analysis to identify ions unique or nearly unique to a single factor or group of factors, as described in detail in Sect. 2.4. Figure 4 shows the results of this analysis as a clustergram. Colors denote the $z$ score of each factor-ion combination. Hierarchical agglomerative clustering was performed independently on (1) the $z$ score profile of each ion across all factors (vertical axis) and (2) the factor profile across all ion $z$ scores (horizontal axis). The outcomes of these cluster analyses are represented as dendrograms on the vertical and horizontal axes, respectively. The ions are clus- tered based on having a similar $z$ score pattern across the factors and the resulting tree is shown on the left, colored subjectively to guide the eye. Clearly, the dendrogram divides the factors into three main groups: one group including CS-OA $_{\text {EESI, PBOAEESI, and LABB2 }}{ }_{\text {EESI }}$; a biomass burning group (LABB1 $1_{\mathrm{EESI}}$ and $\left.\mathrm{MABB} \mathrm{EESI}_{\mathrm{E}}\right)$; and a biogenic $\mathrm{OA}$ group (BSOAEESI and SMOAEESI $_{\text {E }}$. Key ions are defined as those having a $z$ score $>1.5$ for a given factor. These ions are shown in Fig. 5 as stacked histograms binned by the number of carbon atoms, with colors denoting chemical family $\left(\mathrm{C}_{x} \mathrm{H}_{y} \mathrm{~N}, \mathrm{C}_{x} \mathrm{H}_{y} \mathrm{NO}_{z}\right.$, and $\mathrm{C}_{x} \mathrm{H}_{y} \mathrm{O}_{z}$, with the latter further separated by the $\mathrm{H}: \mathrm{C}$ ratio). The left column displays these ions in terms of their relative intensity within each factor profile, while the right column shows the number of identified ions. A full list of the identified key ions is given in Table S1 in the Supplement.

Overall, for all the EESI-TOF factors, the assigned ions exhibit systematic patterns supporting the above identification. Figure $6 \mathrm{a}$ and $\mathrm{b}$ show the mass defect, defined as the exact $m / z$ minus the nearest integer $m / z$, as a function of $m / z$ for the uniquely assigned ions for the seven factors. For several displayed factors, linear correlations or clusters of points are observed. Figure $6 a$ shows the majority of the distinguished molecules (defined as factor-specific ions) of LABB $1_{\text {EESI }}$ and CS-OAEESI factors spread tightly from $m / z 100$ to 400 , while the factor of LABB2 ${ }_{\text {EESI }}$ clusters from $m / z 300$ to 400 with a few additional points from $m / z 150$ to 200 . The mass defects of the LABB $1_{\text {EESI-factor-specific }}$ ions are lower than the CS-OA $\mathrm{EESI}_{-}$and LABB2 2 ESI-factorspecific ions, which indicates that there are more aromatic ions (with a lower $\mathrm{H}: \mathrm{C}$ ratio) in the LABB1 factor. The slope for the LABB $1_{\mathrm{EESI}}$ factor of $4.6 \times 10^{-4}$ is consistent with addition of $\mathrm{CH}$ groups, which yield a slope of $6 \times 10^{-4}$ (mass of $\mathrm{CH}$ is 13.00783 , so slope corresponds to mass defect of 0.00783 added over $13 \mathrm{~m} / \mathrm{z}$ ). It is also consistent with the slope of the primary biomass burning source from a Zurich field campaign (with a slope of $4.9 \times 10^{-4}$, Qi et al., 2019). Here, the slope of the CS-OAEESI factor is $6.4 \times 10^{-4}$, while the slope of the CS-OA factor from the Zurich field campaign is $8 \times 10^{-4}$. As shown in Fig. 6b, the mass of the markers of the PBOAEESI factor spread from $\mathrm{m} / \mathrm{z} 250$ to 400 with a high mass defect. A general trend is that the mass defect value of the BSOAEESI factor is a slightly higher than of the SMOAEESI factor. Both the slopes of BSOAEESI $\left(8.7 \times 10^{-4}\right)$ and SMOAEESI $\left(7.0 \times 10^{-4}\right)$ are consistent with the addition of $\mathrm{CHO}$ functional groups, which would yield a slope of $1 \times 10^{-3}$ (mass defect of 0.00274 over $29 \mathrm{~m} / z$ ).

\subsection{EESI-TOF source apportionment factors}

\section{Cigarette-smoke-related OA (CS-OAEESI)}

The CS-OAEESI time series lacks a clear seasonal trend. However, as shown in Fig. 2a, it correlates strongly with the EESI-TOF nicotine ion $(R=0.89)$. As a reduced nitrogen 

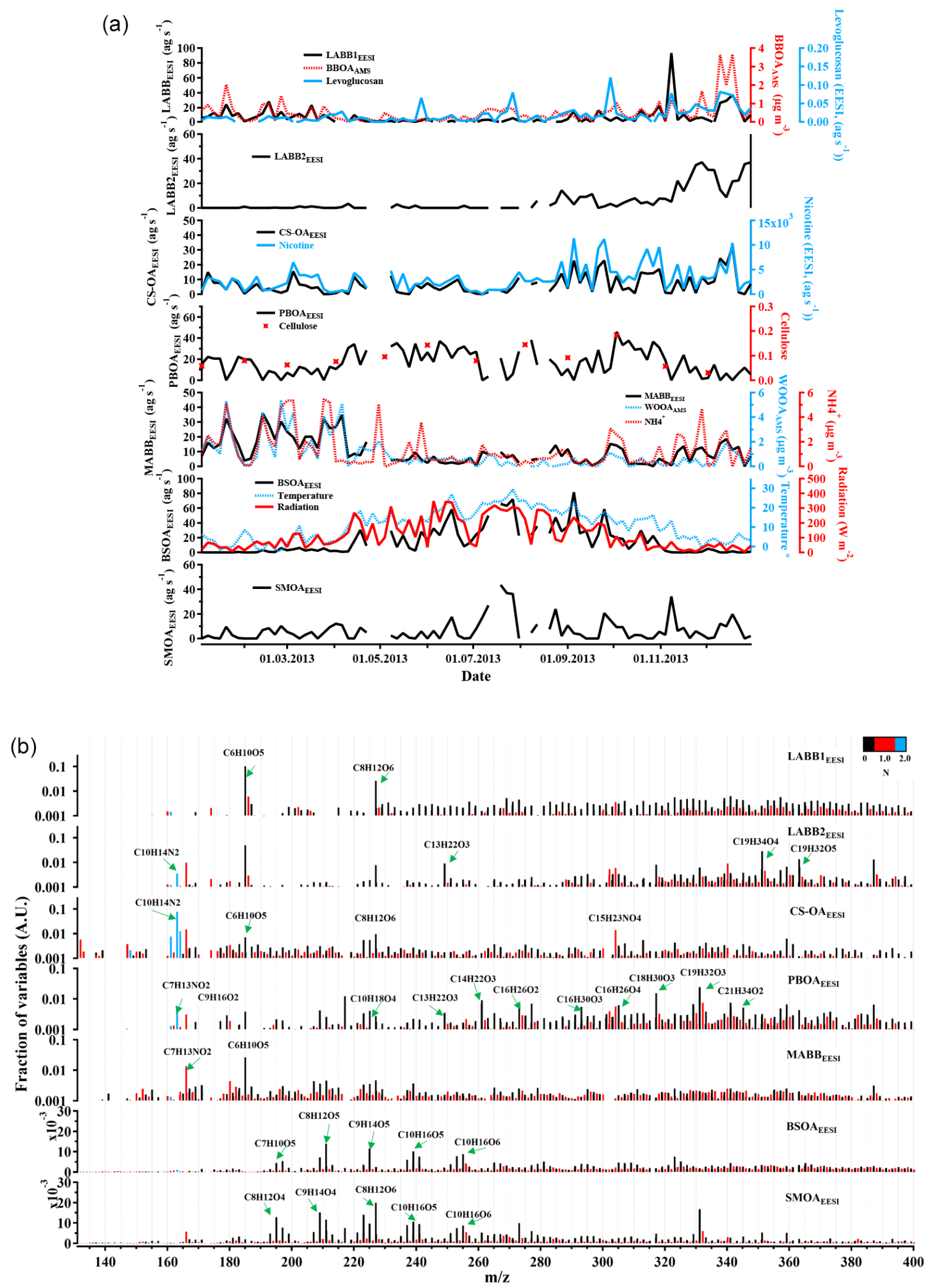

Figure 2. (a) Time series of the EESI-TOF PMF analysis for the seven-factor solution, along with ancillary data. (b) Corresponding factor profiles. For all $y$ axes, EESI-TOF data are shown as mass flux $\left(\mathrm{ag} \mathrm{s}^{-1}\right)$, AMS data are shown in $\mu \mathrm{g} \mathrm{m}^{-3}$, and other units are given. 

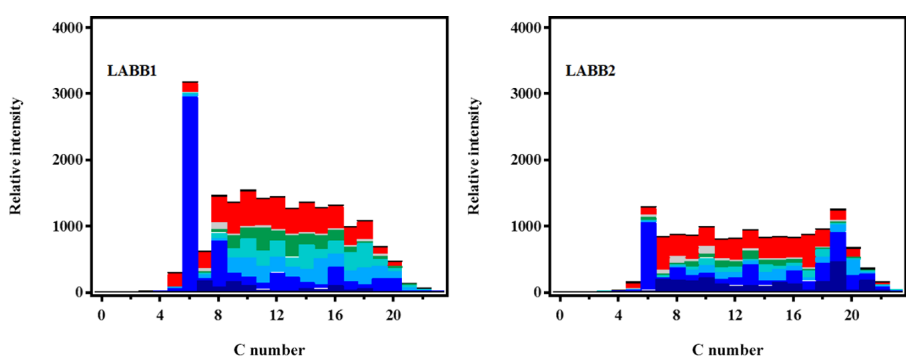

$$
\begin{aligned}
& \text { CHNO } \\
& \text { CHN } \\
& \text { CHO: } \\
& \mathrm{H}: \mathrm{C}<1.1 \\
& 1.1<=\mathrm{H}: \mathrm{C}<1.3 \\
& 1.3<=\mathrm{H}: \mathrm{C}<1.5 \\
& 1.5<=\mathrm{H}: \mathrm{C}<1.7 \\
& \mathrm{H}: \mathrm{C}>1.7
\end{aligned}
$$
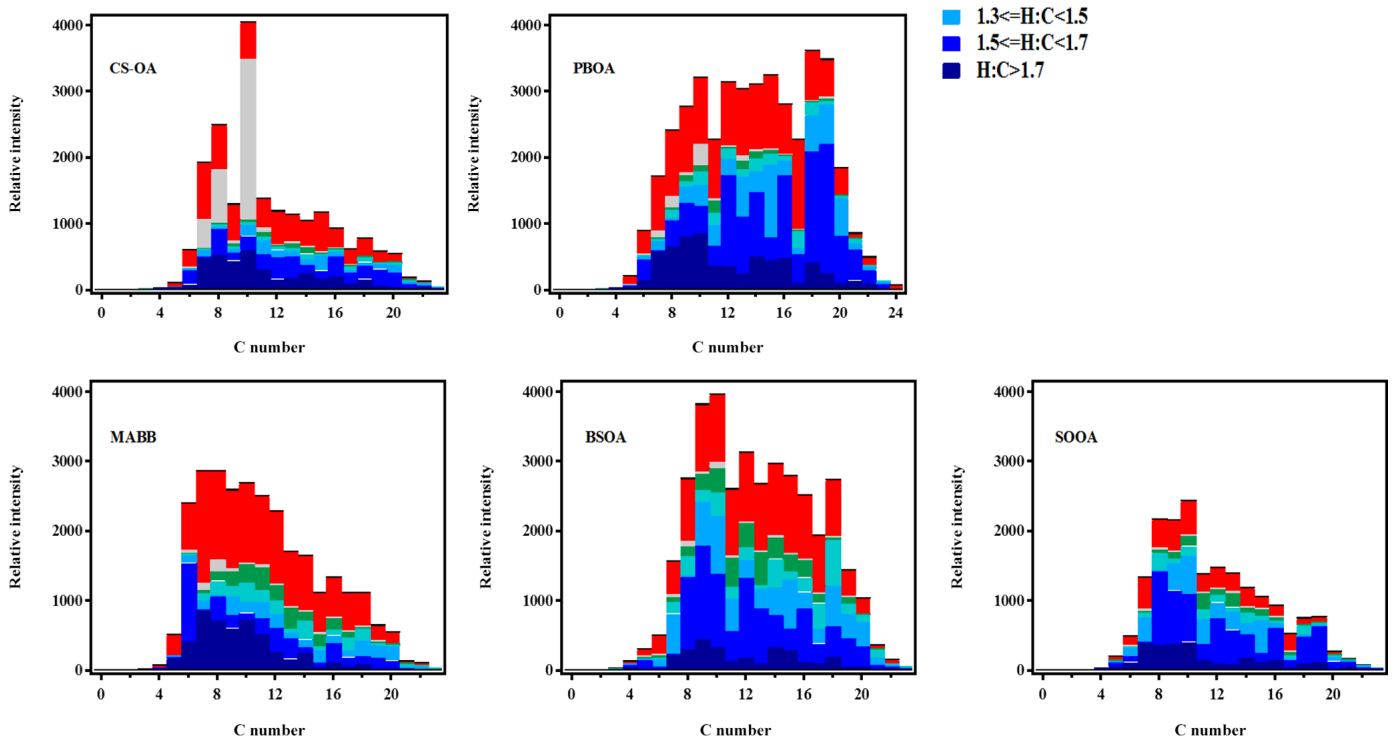

Figure 3. Stacked histogram binned by carbon number of ions, showing the apportioned intensity of each bin to each factor. Colors correspond to seven families.

compound, nicotine likely forms a stable ion by abstracting a hydrogen from water, leading to the observed cation. The stacked histogram of the CS-OA factor (Fig. 3) is unique among the resolved factors in having strong contributions from the $\mathrm{CHN}$ family. Other significant contributions come from $\mathrm{C}_{6} \mathrm{H}_{10} \mathrm{O}_{5}$ and $\mathrm{C}_{8} \mathrm{H}_{12} \mathrm{O}_{6}$ (Fig. 2b). As discussed above, these species are also prevalent in biomass combustion and may occur in this factor due to combustion of biomass in the cigarette.

Oxidized nitrogen (ON) species $\left(\mathrm{C}_{x} \mathrm{H}_{y} \mathrm{O}_{z} \mathrm{~N}_{1}\right.$ and $\mathrm{C}_{x} \mathrm{H}_{y} \mathrm{O}_{z} \mathrm{~N}_{2}$ ) are significant in the CS-OAEESI factor, as shown in Fig. S6c. It is only slightly oxygenated, with an $\mathrm{O}: \mathrm{C}$ ratio below 0.2 , and has a high $\mathrm{H}: \mathrm{C}$ ratio of approximately 1.9. The field measurements at the same site had identified a cigarette smoke factor with a spectral fingerprint similar to $\mathrm{C}_{10} \mathrm{H}_{14} \mathrm{~N}_{2}$ (Qi et al., 2019; Stefenelli et al., 2019). As shown in Fig. 5, the factor-specific ions of the CS-OA factor from cluster analysis have high abundance of $\mathrm{CHNO}, \mathrm{CHN}$ and a high $\mathrm{H}: \mathrm{C}$ ratio $(>1.5)$, which is consistent with our discussion that the factor is primary and dominated by the nitrogen-containing species.

\section{Primary biological organic aerosol (PBOA EESI $)$}

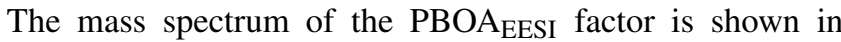
Fig. 2b. Strong contributions from slightly oxygenated ions with high carbon number and high $\mathrm{H}: \mathrm{C}$ ratios, such as $\mathrm{C}_{19} \mathrm{H}_{32} \mathrm{O}_{3}, \mathrm{C}_{18} \mathrm{H}_{30} \mathrm{O}_{3}, \mathrm{C}_{14} \mathrm{H}_{22} \mathrm{O}_{3}, \mathrm{C}_{16} \mathrm{H}_{26} \mathrm{O}_{2}$, and $\mathrm{C}_{9} \mathrm{H}_{16} \mathrm{O}_{2}$, are consistent with fatty acids identified from plants (http: //plantfadb.org, last access: 19 December 2019) (Tervahattu et al., 2005; Schilling et al., 2016). As shown in Fig. 3, the overall mass spectrum of the PBOAEESI factor is shifted towards ions with a higher carbon number (i.e., $\mathrm{C}_{12}$ to $\mathrm{C}_{20}$ ) relative to the other factors. Figure 4 shows that the ions with high $z$ score in PBOAEESI are mostly unique to this factor. These ions are characterized by high carbon number and high $\mathrm{H}: \mathrm{C}$ ratio, as shown in Fig. 5. Of all the factors, only LABB2 $2_{\text {EESI }}$ (discussed below) has unique ions with a comparably high carbon number distribution; however, the factor-specific ions of these two factors are not overlapping Fig. 5).

The PBOAEESI factor is observed throughout the year, with slightly higher contributions during summer (Figs. 2a, S9). PBOA typically consists of solid airborne particles derived from biological organisms, including microorganisms and fragments of biological materials such as plant debris 


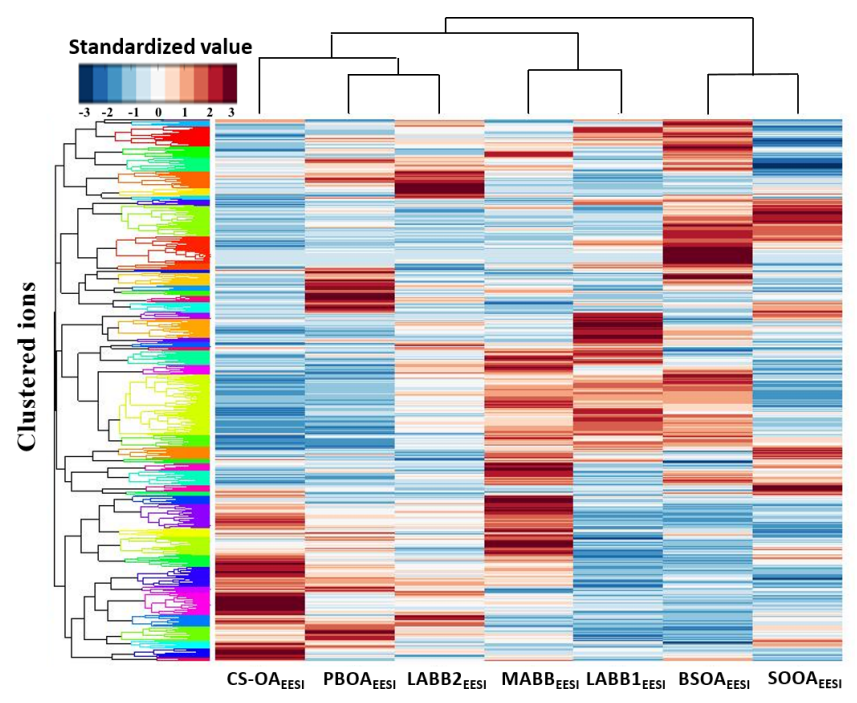

Figure 4. Standardized matrix of individual EESI-TOF ions vs. EESI-TOF PMF factors, colored by $z$ score. Ions and factors are sorted according to the results of their respective hierarchical clustering analysis; the resulting dendrograms are shown on the respective axes. The color of the compounds' groups in the dendrogram are chosen to make groupings convenient to read (dendrogram colors are chosen arbitrarily to aid the eye)

and animal dander (Després et al., 2012). PBOA has been observed previously as a significant source of coarse aerosol organic matter $(\mathrm{OM}$, aerodynamic diameter $>2.5 \mu \mathrm{m})$ in Switzerland (Després et al., 2012; Bozzetti et al., 2016; Vlachou et al., 2018). The most frequently occurring biopolymer in terrestrial environments is cellulose, as around $50 \%$ of dry weight cellulose is from leaves (Sánchez-Ochoa et al., 2007; Jaenicke, 2005). Atmospheric "free cellulose" has been determined as a proxy for plant debris. As shown in Fig. 2a, cellulose correlates with the PBOA $\mathrm{EESI}_{\text {time series }}(R=0.83)$ much more strongly than with any other EESI-TOF factor $(R<0.3)$, although the number of cellulose measurements is limited to only 12 filters. Nevertheless, like the factor mass spectrum this correlation is consistent with the assignment of this factor to PBOA.

We also considered cooking-related emissions as an alter-

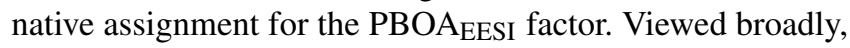
these two emissions sources are somewhat similar in that they are both expected to have strong contributions from fatty acids, consistent with the salient features of the PBOAEESI mass spectrum. Indeed, a $\mathrm{COA}_{\mathrm{AMS}}$ factor is resolved, but no $\mathrm{COA}$ is retrieved from the EESI-TOF dataset despite previous studies identifying online cooking emissions in EESITOF data during summer and winter (Fig. S10) at the same site. However, offline AMS analyses have previously shown COA to have a low extraction efficiency (Daellenbach et al., 2016), resulting in low contribution in the EESI-TOF dataset. Further, the highest $\mathrm{COA}_{\mathrm{AMS}}$ concentrations occur during the period of 14 April-8 May, during which no EESI-TOF data are available. Without this strong temporal feature, COA may contribute too little to the variability of the EESI-TOF dataset to be resolved. A detailed comparison of the retrieved

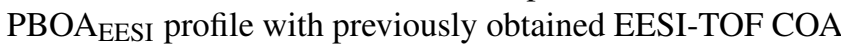
factors shows that dominant PBOA $_{\mathrm{EESI}}$ ions are different from the major components of cooking-related EESI-TOF factors obtained from source apportionment of online summer and winter mass data, e.g., $\mathrm{C}_{16} \mathrm{H}_{30} \mathrm{O}_{3}, \mathrm{C}_{18} \mathrm{H}_{34} \mathrm{O}_{2}$ (Stefenelli et al., 2019; Qi et al., 2019). Further, we note that the time series of the PBOA ${ }_{\mathrm{EESI}}$ and $\mathrm{COA}_{\mathrm{AMS}}$ factors are not well correlated, suggesting different sources and thus a unique source for PBOA $\mathrm{EESI}_{\mathrm{E}}$ unrelated to cooking emissions.

\section{Less aged biomass burning factors (LABB1 $1_{\text {EESI }}$ and LABB2 EESI)}

Two factors were attributed to relatively fresh biomass burning emissions, denoted here as less aged biomass burning type 1 and 2 (LABB1 $1_{\mathrm{EESI}}$ and LABB2 $2_{\mathrm{EESI}}$, respectively). LABB1 $1_{\mathrm{EESI}}$ displays many characteristics that are similar to primary or slightly aged wood burning emissions from previous EESI-TOF and AMS source apportionment studies. The time series of the LABB1 $1_{\mathrm{EESI}}$ factor is correlated with the $\mathrm{BBOA}_{\mathrm{AMS}}$ factor $\left(R=0.6\right.$, Fig. 2a). LABB $1_{\mathrm{EESI}}$ also correlates with the $\mathrm{C}_{6} \mathrm{H}_{10} \mathrm{O}_{5}$ ion measured by the EESITOF ( $R=0.43$ ), corresponding to levoglucosan and its isomers, which are well-known tracers of biomass combustion. LABB $1_{\text {EESI }}$ shows a pronounced yearly cycle with high concentration during both winters, consistent with previous studies identifying biomass burning as a major source of wintertime OA in Zurich and central Europe (Crippa et al., 2013a, 2014; Bozzetti et al., 2016; Bruns et al., 2016). The factor profile is dominated by the ions of $\mathrm{C}_{6} \mathrm{H}_{10} \mathrm{O}_{5}$ and $\mathrm{C}_{8} \mathrm{H}_{12} \mathrm{O}_{6}$ as shown in Fig. 2b, similar to fresh wood burning emissions resolved by source apportionment of online EESI-TOF data (Qi et al., 2019). Although the EESI-TOF provides only a molecular formula and not structural information, we note that the dominant contribution of a very small number of ions (i.e., $\mathrm{C}_{6} \mathrm{H}_{10} \mathrm{O}_{5}$ and $\mathrm{C}_{8} \mathrm{H}_{12} \mathrm{O}_{6}$ ) to the factor profile suggests that these ions result from a process such as cellulose pyrolysis, which gives rise to a relatively small number of discrete major products (including levoglucosan) as opposed to oxidative processing, which is characterized by more complex branching pathways and thus a broader distribution of chemically related compounds (e.g., homologous ion series). As a result, the $\mathrm{C}_{8} \mathrm{H}_{12} \mathrm{O}_{6}$ ion is likely also a pyrolysis product or other primary emission and not, for example, MBTCA (3-methyl-1,2,3,-butanetricarboxylic acid), which is an important product of $\alpha$-pinene oxidation. Figures 3 and S6 show that, in addition to the strong contributions from $\mathrm{C}_{6} \mathrm{H}_{10} \mathrm{O}_{5}$ and $\mathrm{C}_{8} \mathrm{H}_{12} \mathrm{O}_{6}$, LABB1 $1_{\mathrm{EESI}}$ is unique among the retrieved factors in having a higher fractional signal from ions with low $\mathrm{H}: \mathrm{C}$ value. This trend is amplified in the key ions identified from the clustergram analysis (Fig. 4), as shown in Fig. 5, where (aside from $\mathrm{C}_{6} \mathrm{H}_{10} \mathrm{O}_{5}$ and $\mathrm{C}_{8} \mathrm{H}_{12} \mathrm{O}_{6}$ ), the 

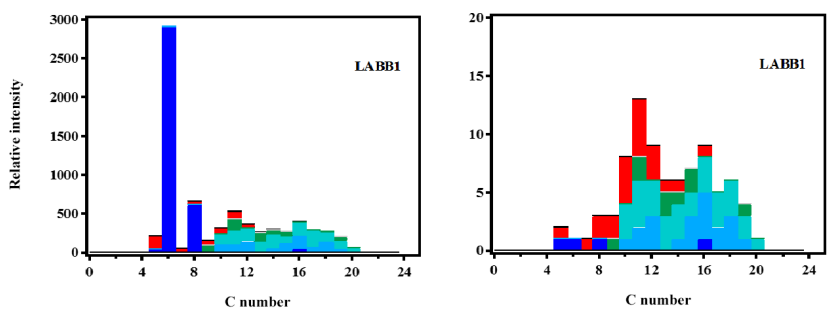

- CHNO

- $\mathrm{CHN}$

CHO:

- $\mathrm{H}: \mathrm{C}<1.1$

$1.1<=\mathrm{H}: \mathrm{C}<1.3$

$1.3<=\mathrm{H}: \mathrm{C}<1.5$

- $1.5<=\mathrm{H}: \mathrm{C}<1.7$

- $\mathrm{H}: \mathrm{C}>1.7$
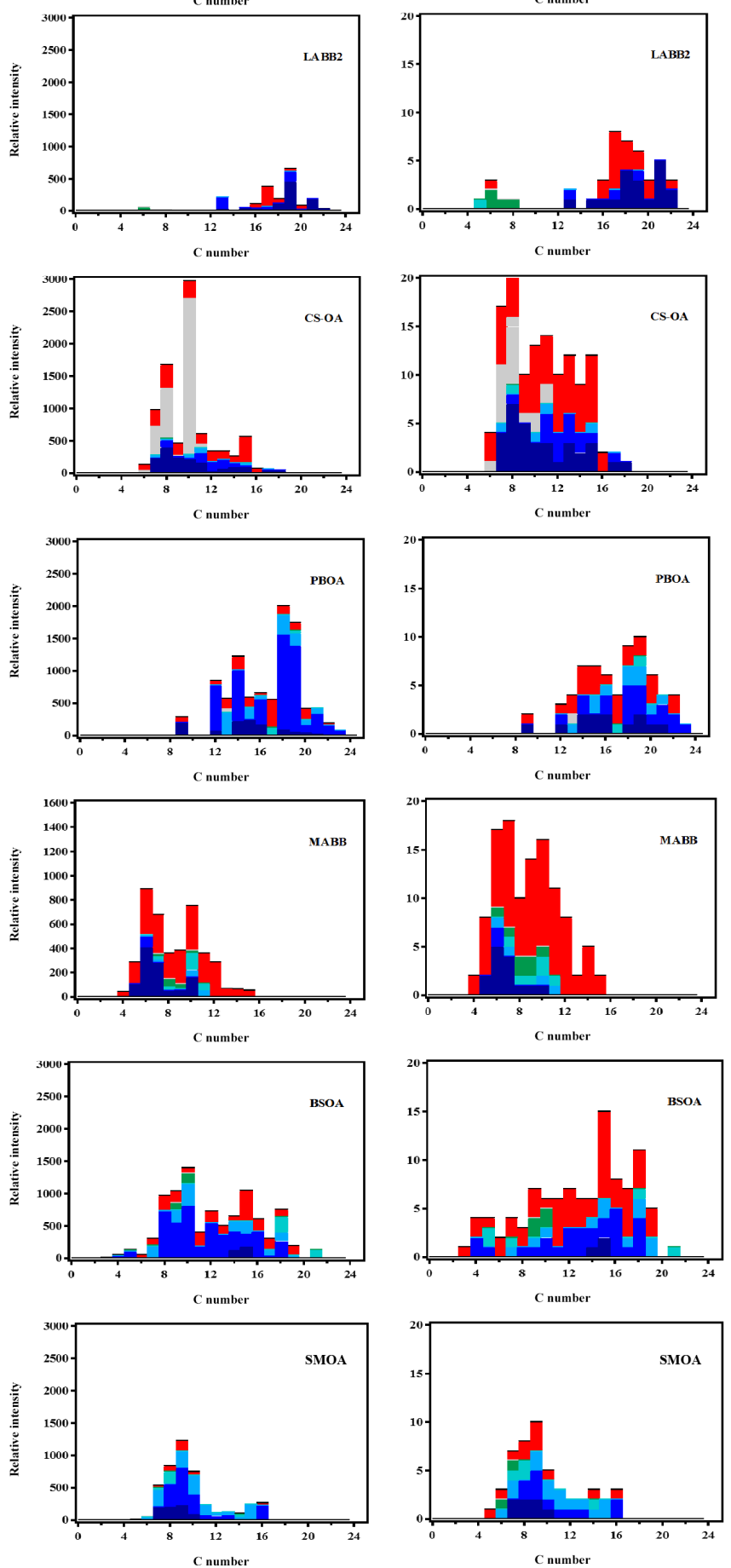

Figure 5. Stacked histogram binned by carbon number and colored by chemical family of key ions derived from clustergram analysis of factor mass spectra. Two representations are shown, with the stacked height denoting ion intensity (left column) or number of identified ions (right column). 

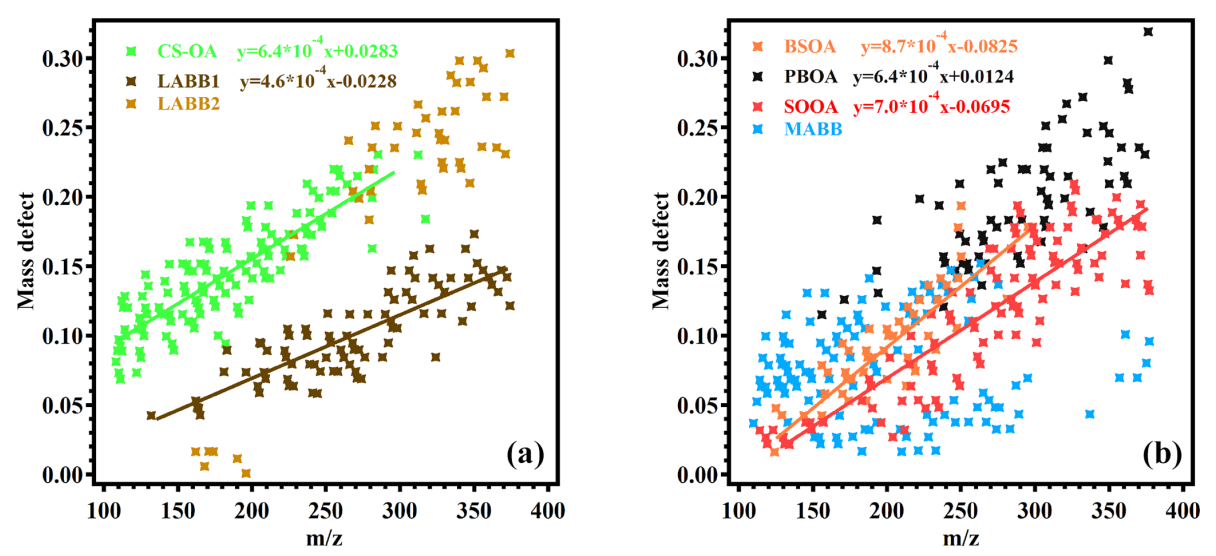

Figure 6. Mass defect plots of factor-specific ions (identified from the cluster analysis) for selected EESI-TOF POA (a) and SOA (b) factors.

ions unique to LABB1 $1_{\mathrm{EESI}}$ consist almost entirely of ions with $\mathrm{H}: \mathrm{C}<1.5$. This contrasts sharply with the other factors, where ions with low $\mathrm{H}: \mathrm{C}$ are rare. The low $\mathrm{H}: \mathrm{C}$ may indicate more aromatic character due to combustion origins of primary $\mathrm{OA}$ and/or oxidation products of aromatics, which may include significant contribution from ring-opening reactions.

The LABB2 $2_{\mathrm{EESI}}$ factor is enhanced during the second winter only, while concentrations during the first winter are indistinguishable from those during summer. Concentrations begin to increase in September, and continue increasing throughout the rest of the year. Because the filter samples were measured in random sequence, this does not reflect an artifact of the offline EESI measurement system, such as a drift in EESI-TOF performance or gradual contamination of the aerosol generation system. It is therefore likely that this time series represents a real feature of the aerosol composition. The scatter plots (Fig. S8) show that the sum of the LABB1 $1_{\mathrm{EESI}}+\mathrm{LABB} 2_{\mathrm{EESI}}$ factors has a higher correlation with $\mathrm{BBOA}_{\mathrm{AMS}}$ than $\mathrm{LABB} 1_{\mathrm{EESI}}$ alone. The mass spectrum of LABB2 2 EESI is dominated by $\mathrm{C}_{6} \mathrm{H}_{10} \mathrm{O}_{5}$ and $\mathrm{C}_{8} \mathrm{H}_{12} \mathrm{O}_{6}$, with high contributions of $\mathrm{C}_{19}-\mathrm{C}_{21}$ ions (14\% to the factor). This is demonstrated by the cluster analysis (Fig. 5, Table S1), which indicates that the factor-specific ions with $\mathrm{C}_{19}$ and $\mathrm{C}_{21}$ are predominantly in this factor. The Van Krevelen plot (Fig. S6b) shows that this factor is dominated by ions with a high $\mathrm{H}: \mathrm{C}$ ratio (above 1.7, Fig. 5), low $\mathrm{O}: \mathrm{C}$ ratio (below 0.25 ), and high carbon number, which is consistent with our identification that the factor is likely from primary emissions (Bertrand et al., 2018; Elser et al., 2016).

\section{More aged biomass burning OA (MABB EESI $)$}

The time series of $\mathrm{MABB}_{\mathrm{EESI}}$ and $\mathrm{WOOA}_{\mathrm{AMS}}$ are strongly correlated (Fig. 2a, $R=0.85$ ). Both also have a strong correlation with the secondary aerosol component $\mathrm{NH}_{4}^{+}(R=$

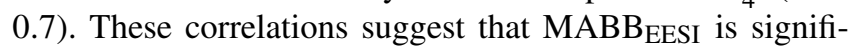
cantly influenced by SOA. However, a strong contribution from $\mathrm{C}_{6} \mathrm{H}_{10} \mathrm{O}_{5}$ is also observed, suggesting that the factor also contains primary emissions, although this POA species comprises a substantially lower fraction of the total factor than in LABB1 $1_{\mathrm{EESI}}$ and $\mathrm{LABB} 2_{\mathrm{EESI}}$. As also shown in Fig. 2b, major components of the MABB $\mathrm{EESI}_{\text {mass spectrum }}$ (e.g., $\mathrm{C}_{6} \mathrm{H}_{10} \mathrm{O}_{5}, \mathrm{C}_{7} \mathrm{H}_{8} \mathrm{O}_{5}, \mathrm{C}_{9} \mathrm{H}_{16} \mathrm{O}_{4}$, and $\mathrm{C}_{8} \mathrm{H}_{12} \mathrm{O}_{6}$ ) are similar to those in mass spectra of aged biomass burning emissions retrieved from smog chamber experiments (Bertrand et al., submitted) and MABB factors from source apportionment of online EESI-TOF data from a winter study in Zurich (Qi et al., 2019). Figure S11 shows the distinct low relative contribution of $\mathrm{C}_{6} \mathrm{H}_{10} \mathrm{O}_{5}$ and $\mathrm{C}_{8} \mathrm{H}_{12} \mathrm{O}_{6}$ ions to the $\mathrm{MABB}_{\text {EESI }}$ factor.

Figure 7 shows that the factor-specific ions of the $\mathrm{MABB}_{\mathrm{EESI}}$ factor are classified into two distinct populations (Fig. 6b), with lower $\mathrm{H}: \mathrm{C}$ and higher $\mathrm{O}: \mathrm{C}$ ratio on the one hand and higher $\mathrm{H}: \mathrm{C}$ and lower $\mathrm{O}: \mathrm{C}$ ratio on the other hand. These two populations are consistent with the stacked histogram of MABB shown in Fig. 5. The lower mass defect population with lower $\mathrm{H}: \mathrm{C}$ ratio is consistent with phenol / cresol oxidation enriched with $\mathrm{C}_{6}: \mathrm{C}_{7}$ ions, which are known as important biomass burning SOA precursors (Burns et al., 2016). The higher mass defect population with higher $\mathrm{H}: \mathrm{C}$ ratios was composed of $\mathrm{CHON}$ and $\mathrm{CHO}$ group ions. Furthermore, phenol SOA has been shown to have a low relative response factor (RRF) in EESI-TOF, indicating an underestimation of these ions (Lopez-Hilfiker et al., 2019).

\section{Biogenic secondary organic aerosol $\left(\right.$ BSOA $\left._{\text {EESI }}\right)$ and summer mixed oxygenated organic aerosol (SMOA EESI)}

Both BSOA $A_{\text {EESI }}$ and SMOAEESI factors show elevated concentrations in summer and have negligible contributions from levoglucosan $\left(\mathrm{C}_{6} \mathrm{H}_{10} \mathrm{O}_{5}\right)$. The BSOAEESI factor exhibits a high contribution during warm seasons (spring and summer) but is near zero during winter (Fig. 2a). The time series of the SMOAEESI factor also shows an elevated contribution in summer but differs from BSOA $\mathrm{EESI}_{\text {in }}$ that it also has 

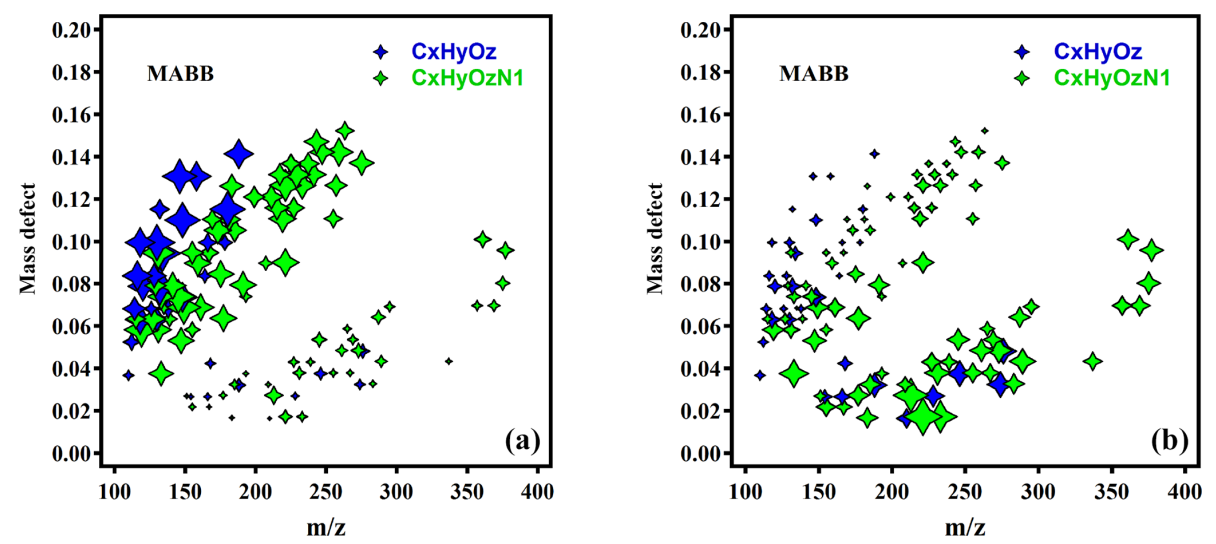

Figure 7. Mass defect plot of factor-specific ions for the $\mathrm{MABB}_{\mathrm{EESI}}$ factor colored by nitrogen number and sized by $\mathrm{H}: \mathrm{C}$ ratio $(\mathbf{a})$ and $\mathrm{O}: \mathrm{C}$ ratio (b).

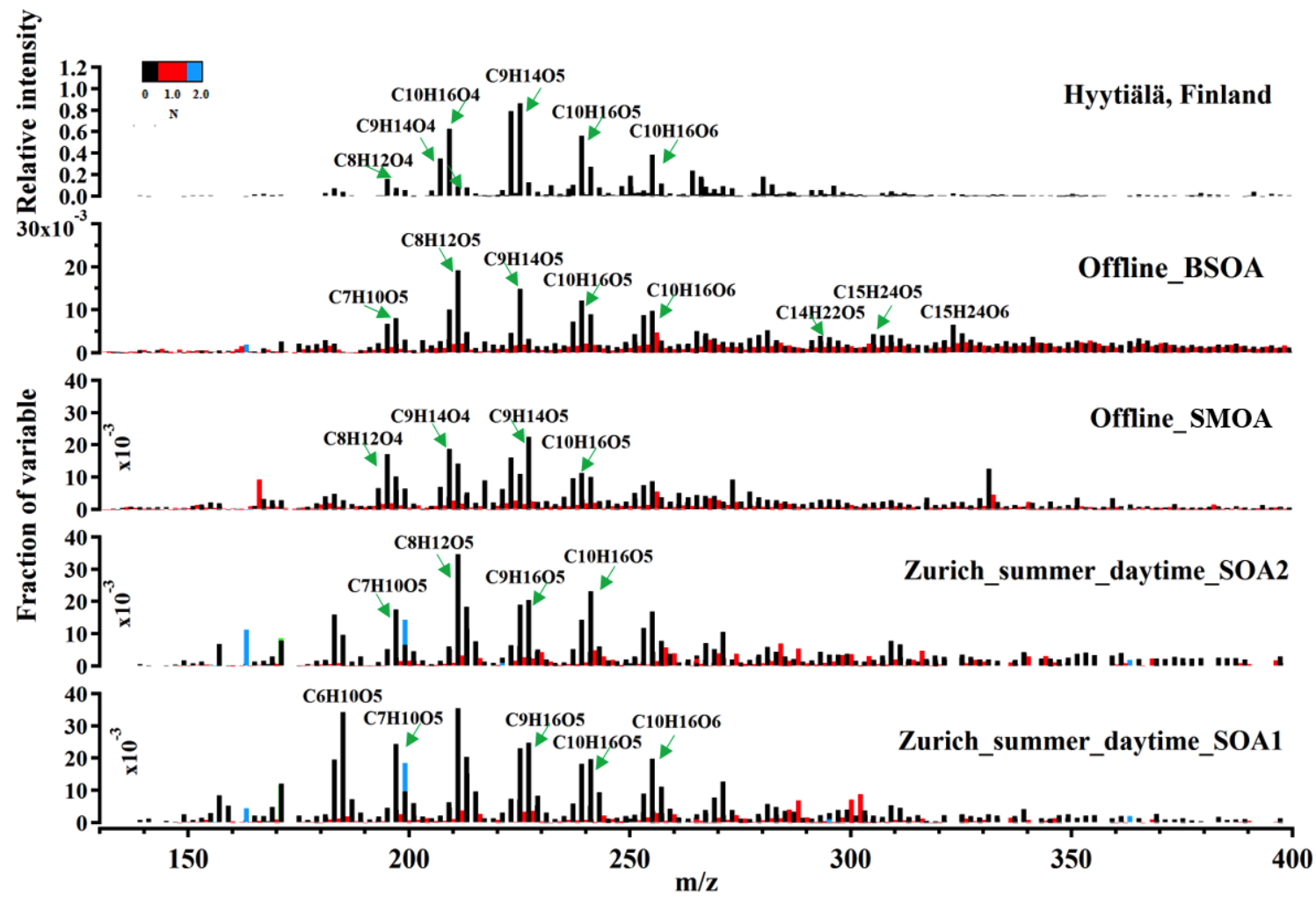

Figure 8. Comparison of the offline summer factor profiles with mass spectra from the Hyytiälä field campaign and the online summer factors. The total signal of each factor is normalized to unity.

nonzero contribution in winter. Figure S11 (Fig. S13) shows the correlation of the three factors with the ambient temperature. While the SMOAEESI factor does not show a clear dependency on temperature, $\mathrm{BSOA}_{\mathrm{EESI}}$ increases exponentially with temperature, consistent with the known relationship for terpene emissions and biogenic aerosol in terpene-dominated regions. While $\mathrm{SOOA}_{\mathrm{AMS}}$ stems largely from biogenic precursors, this factor likely also includes a smaller proportion of compounds from other sources, whereas BSOAEESI represents rather pure biogenic SOA.

Figure $2 \mathrm{~b}$ shows that the ions with the highest signal in $\mathrm{BSOA}_{\text {EESI }}$ are $\mathrm{C}_{7} \mathrm{H}_{10} \mathrm{O}_{5}, \mathrm{C}_{8} \mathrm{H}_{12} \mathrm{O}_{5}, \mathrm{C}_{9} \mathrm{H}_{14} \mathrm{O}_{5}$, $\mathrm{C}_{10} \mathrm{H}_{16} \mathrm{O}_{5}$, and $\mathrm{C}_{10} \mathrm{H}_{16} \mathrm{O}_{6}$, while other ions, i.e., $\mathrm{C}_{14} \mathrm{H}_{22} \mathrm{O}_{5}$, $\mathrm{C}_{15} \mathrm{H}_{22} \mathrm{O}_{5}, \mathrm{C}_{15} \mathrm{H}_{24} \mathrm{O}_{5}$, and $\mathrm{C}_{15} \mathrm{H}_{22} \mathrm{O}_{6}$, are tentatively identified as sesquiterpene oxidation products. This differs slightly from $\mathrm{SMOA}_{E E S I}$, where $\mathrm{C}_{8} \mathrm{H}_{12} \mathrm{O}_{4}, \mathrm{C}_{9} \mathrm{H}_{14} \mathrm{O}_{4}, \mathrm{C}_{9} \mathrm{H}_{16} \mathrm{O}_{5}$, $\mathrm{C}_{10} \mathrm{H}_{16} \mathrm{O}_{4}$, and $\mathrm{C}_{10} \mathrm{H}_{16} \mathrm{O}_{5}$ show the strongest signals. Fig- 

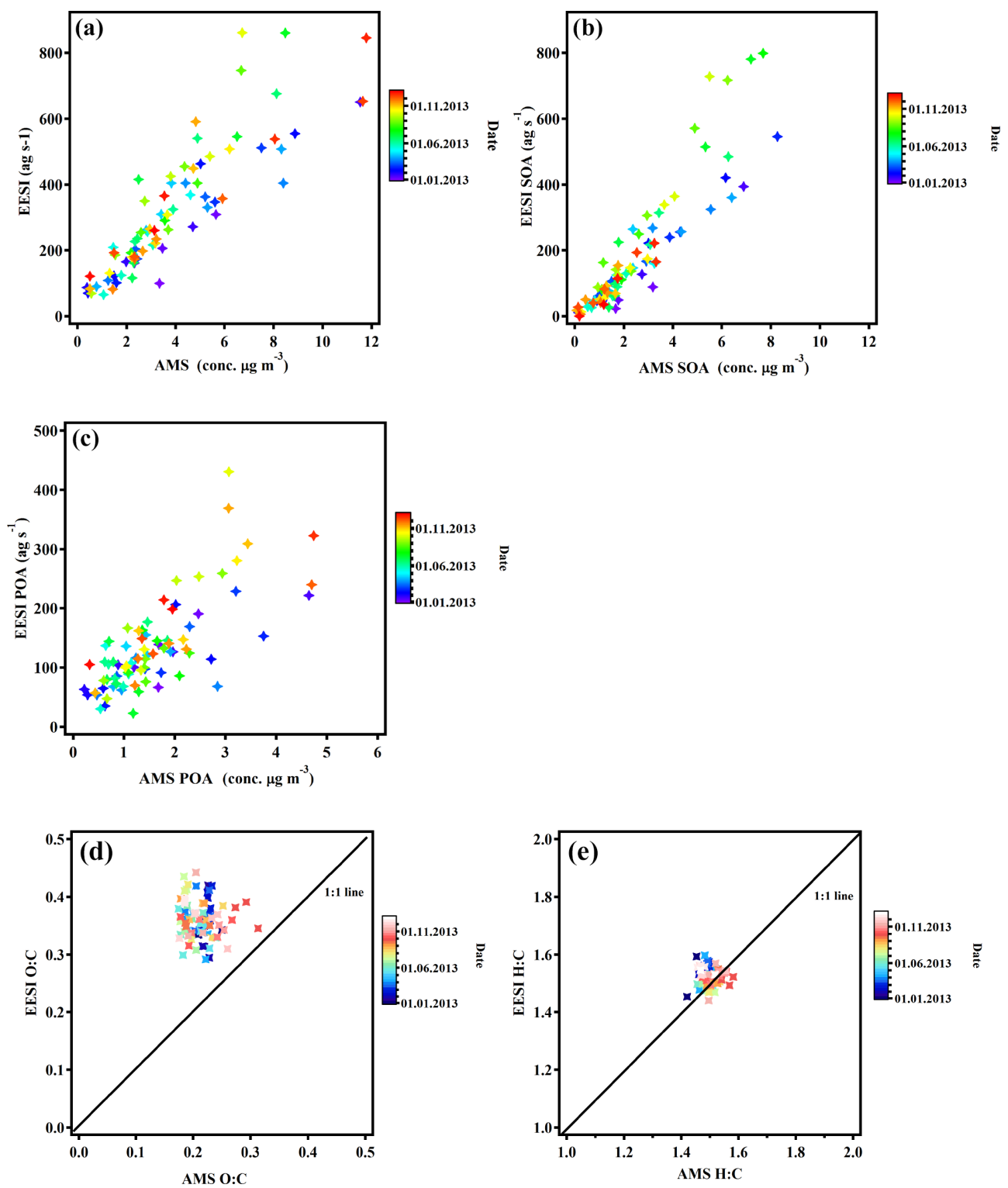

Figure 9. Comparison of EESI-TOF and AMS: total EESI-TOF mass flux (ag s ${ }^{-1}$ ) as a function of AMS OA, points are colored by date (a); total EESI-TOF SOA mass flux $\left(\mathrm{ag} \mathrm{s}^{-1}\right.$ ) as a function of AMS SOA, points are colored by date (b); total EESI-TOF POA mass flux (ag s ${ }^{-1}$ ) as a function of AMS POA, points are colored by date (c); the EESI-TOF and AMS comparison in terms of $\mathrm{O}: \mathrm{C}(\mathbf{d})$ and $\mathrm{H}: \mathrm{C}(\mathbf{e})$, points are colored by date.

ure 3 shows that the $\mathrm{BSOA}_{\mathrm{EESI}}$ factor contains more organic nitrogen species than the SMOAEESI factor. Figure S7b and $\mathrm{c}$ show Van Krevelen plots for these two factors. BSOA $\mathrm{EESI}_{\mathrm{E}}$ has a higher $\mathrm{O}: \mathrm{C}$ ratio than $\mathrm{SMOA}_{\mathrm{EESI}}(1-1.2$ vs. 0.4-0.6). The two factors are compared in more detail in Fig. 5 with the factor-specific ions. The range of $\mathrm{H}: \mathrm{C}$ ratios is between 1.1 and 1.5 for the marker ions in both factors (except for the CHNO family). The carbon numbers of factor-specific ions in $\mathrm{BSOA}_{\mathrm{EESI}}$ factor are spread from $\mathrm{C} 8$ to $\mathrm{C} 21$. The high $\mathrm{C}$ numbers are consistent with the presence of sesquiterpene oxidation products and terpene dimers. The $\mathrm{SMOA}_{\mathrm{EESI}}$ factor, mostly with less than 10 carbon atoms $\left(\mathrm{C}_{7}, \mathrm{C}_{8}, \mathrm{C}_{9}\right.$ and $\mathrm{C}_{10}$ ), likely includes both monoterpene oxidation products (e.g., $\mathrm{C}_{10} \mathrm{H}_{16} \mathrm{O}_{4}, \mathrm{C}_{10} \mathrm{H}_{16} \mathrm{O}_{5}$ ) and ring-opening oxidation products of light aromatics. This is consistent with our temperature comparison above that $\mathrm{BSOA}_{\mathrm{EESI}}$ factor is likely SOA from pure biogenic emissions and that the SMOA $\mathrm{EESI}_{\mathrm{I}}$ factor is likely mixed and regional.

Figure 8 compares these factor mass spectra with a factor dominated by terpene SOA ("Daytime SOA2, Daytime SOA1") derived from PMF analysis of a summer field campaign at the same site in Zurich, as well as a mass spectrum from field measurements during spring in Hyytiälä, Finland, located in a remote boreal forest (Stefenelli et al., 2019; Qi 
et al., 2019; Pospisilova et al., 2020). This comparison shows

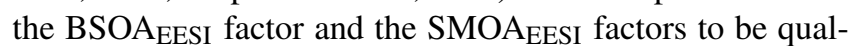
itatively similar to terpene-derived SOA. Additionally, the terpene-derived biogenic SOA has already been identified as a major summertime aerosol source in central Europe (Zhang et al., 2018; Claeys et al., 2007; Ng et al., 2007; Canonaco et al., 2015; Daellenbach et al., 2017).

\subsection{EESI-TOF and AMS comparison}

For the comparison of EESI-TOF and AMS results, no relative sensitivity corrections were applied to the EESI-TOF data, although it is known that compound-dependent differences exist (Lopez-Hilfiker et al., 2019). Figure 9a shows the total ion signal $\left(\mathrm{ag} \mathrm{s}^{-1}\right)$ measured by the EESI-TOF as a function of the OA concentration measured by the AMS, with the points colored by date. Agreement is generally good, except during winter, where the ratio of EESI-TOF to AMS is lower. This corresponds to high fractional contributions from the EESI biomass burning factors, especially the SOA-

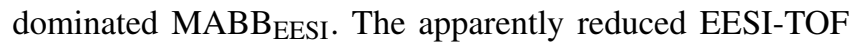
response is thus likely driven by the lower EESI-TOF sensitivity to SOA from light aromatics compared to terpenes (Lopez-Hilfiker et al., 2019). Figure 9b shows the mass flux of EESI-TOF SOA signal (MABB + BSOA + SMOA) as a function of AMS SOA mass, colored by date, while Fig. 9c shows the comparison between EESI-TOF POA and AMS POA, correlating well with each other. Similar to Fig. 9a, the SOA-dominated period toward the winter exhibits a lower relative sensitivity for the EESI-TOF than the terpenedominated summer season.

Figures $9 \mathrm{~d}$ and e show the $\mathrm{O}: \mathrm{C}$ and $\mathrm{H}: \mathrm{C}$ atomic ratios, respectively, for the EESI-TOF vs. those of the AMS. The estimated $\mathrm{O}: \mathrm{C}$ ratios by the EESI-TOF (around 0.30.45 , again with no ion-dependent response factors applied) are systematically higher than those measured by the AMS (around 0.2-0.3). This bias is similar to that observed in online data for winter and summer aerosol in Zurich (Stefenelli et al., 2019; Qi et al., 2019). On the other hand, the H : C ratios of these two instruments show fair consistency with values around 1.5 for the EESI-TOF and AMS analyses. This is not consistent with our observations for summer and winter aerosol in Zurich and for aging experiments of wood burning emissions in an environmental chamber, where all measured $\mathrm{H}: \mathrm{C}$ ratios were higher for the EESI-TOF than for the AMS. Note also that unlike the comparison of total EESI-TOF and AMS signals, there are no seasonally dependent differences in the measured $\mathrm{H}: \mathrm{C}$ or $\mathrm{O}: \mathrm{C}$ ratio.

Figure 10 shows the stacked time series of the AMS PMF factors and EESI-TOF PMF factors. Also shown are pie charts of the mean EESI-TOF factor contributions (Fig. 10c) and the mean AMS factor contributions (Fig. 10d) over the entire measurement period. As discussed earlier, this apportionment specifically describes the WSOM fraction, as no WSOM-to-OM correction factors are applied.
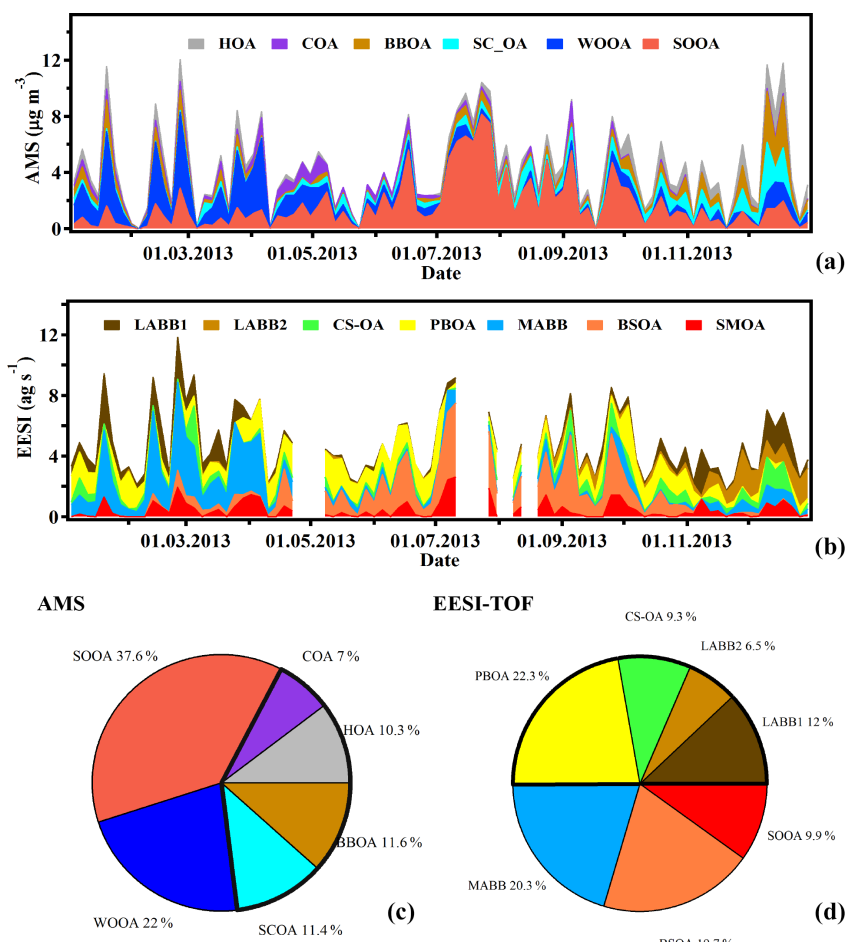

EESI-TOF (b)

Figure 10. Comparison between AMS factors and EESI factors: time series of the concentrations of the AMS PMF factor (a) and mass flux of EESI PMF factor (b). Pie charts of source apportionment results from the EESI (c) and AMS (d).

Overall, the sum of the primary factors of LABB $1_{\mathrm{EESI}}$ $(12 \%)$ and $\mathrm{LABB} 2_{\mathrm{EESI}}(6.5 \%)$ contributes $18.5 \%$ of the EESI-TOF signal and compares with the $\mathrm{BBOA}_{\mathrm{AMS}}$ factor $(12 \%)$. The fraction of secondary MABB $\mathrm{EESI}(20.3 \%)$ factor is a bit lower than the $\mathrm{WOOA}_{\mathrm{AMS}}$ factor $(22 \%)$. The source of CS-OAEESI contributes to $9.3 \%$, which must have contributions from some AMS factors, e.g., from wood burning and cooking. The secondary factors BSOA $\mathrm{EESI}_{\mathrm{E}}(19.7 \%)$ and SMOAEESI $(9.9 \%$ ) contribute $29.6 \%$ of the EESI-TOF signal compared to $37.6 \%$ of the total apportioned mass for the AMS summer factor SOOA. The relatively good agreement between related factors across instruments suggests that compound-dependent sensitivities do not result in a major distortion of the EESI-TOF source apportionment results.

The PBOAEESI factor exhibits the strongest difference, with $22.3 \%$ in the EESI-TOF, while PBOA is not resolved at all in the AMS. Daellenbach et al. (2017) did not separate a PBOA factor in their AMS PMF analysis, either when unconstrained or when using the mass spectral signature from Bozzetti et al. (2016). Three methods (based on factor profiles, coarse OC, and cellulose) were used to estimate the influence of PBOA in Bozzetti et al. (2016), reporting that offline measurement is with a factor of 3 to 10 times lower PBOA in the warm season. Here, the EESI-TOF measurement shows the advantage of measuring the samples 
at molecular level, enabling the separation of PBOA $\mathrm{EESI}_{\text {and }}$

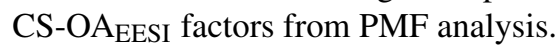

\section{Conclusions}

In this study, we analyzed 91 filters collected at the NABEL monitoring station at Kaserne Park in Zurich, an urban background site. These filters were collected for $24 \mathrm{~h}$ each, approximately every fourth day throughout 2013, and then measured by utilizing the offline AMS method (water extraction followed by re-nebulization and measurement) to the EESI-TOF. It is the first offline work to characterize the secondary organic aerosol sources and composition using a new developed instrument extractive electrospray ionization time-of-flight mass spectrometer (EESI-TOF). The increased chemical specificity of the EESI-TOF allows for additional, meaningful factors to be resolved relative to the AMS.

Positive matrix factorization (PMF) analysis was conducted on the offline EESI-TOF data, yielding seven factors describing water-soluble organic material (WSOM): two less aged biomass burning factors (LABB1 $1_{\mathrm{EESI}}$ and LABB2 $2_{\mathrm{EESI}}$ ) indicating a strong aromatic influence, cigarette smoke organic aerosol (CS-OAEESI, characterized by the contribution from nicotine), primary biological organic aerosol $\left(\right.$ PBOA $\left._{\text {EESI }}\right)$ identified by fatty acids from plants, more aged biomass burning $\left(\mathrm{MABB}_{\mathrm{EESI}}\right)$ characterized by the key feature from wood burning chamber measurement, biogenic

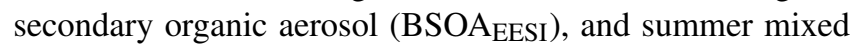

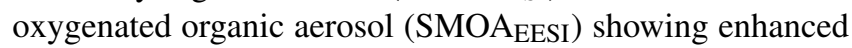
contribution from ions characteristic of monoterpene oxida-

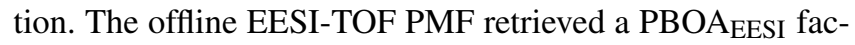
tor, separated less aged and more aged factors from biomass burning, and presented winter- and summer-dominated emissions, features that are not possible for AMS PMF analysis. We performed cluster analysis of the EESI-TOF ions followed by correlation with the resolved factors, which identifies factor-specific ions of each factor. These characteristic ions represent potential markers for future studies.

Overall, the EESI-TOF analysis was supported and corroborated by the AMS PMF analysis. This work highlights the potential of offline, highly chemically resolved data provided by an EESI-TOF for identification of the key sources over a long time period.

Data availability. Data are available from the Zenodo online repository hosted by CERN (https://doi.org/10.5281/zenodo.3930871; Qi et al., 2020).

Supplement. The supplement related to this article is available online at: https://doi.org/10.5194/acp-20-7875-2020-supplement.
Author contributions. LQ was the main author. LQ, ALV, SE, LC, JZ, JLJ, PF, AKG, and KRD conducted the experiment, MC, XG, JGS, ASHP, and UB were the supervisors. All authors contributed to the corrections of the paper.

Competing interests. The authors declare that they have no conflict of interest.

Acknowledgements. Carlo Bozzetti is acknowledged for SoFi training. Felipe Lopez-Hilfiker and Veronika Pospisilova are acknowledged for initial EESI training.

Financial support. This research has been supported by the Swiss National Science Foundation (grant no. BSSGI0_155846), the Swiss National Science Foundation (grant no. 200021_169787), the International ST cooperation program of China (grant no. 2014DFA90780), and the National Natural Science Foundation of China (grant no. 21976093).

Review statement. This paper was edited by John Liggio and reviewed by two anonymous referees.

\section{References}

Bertrand, A., Stefenelli, G., Jen, C. N., Pieber, S. M., Bruns, E. A., Ni, H., Temime-Roussel, B., Slowik, J. G., Goldstein, A. H., El Haddad, I., Baltensperger, U., Prévôt, A. S. H., Wortham, H., and Marchand, N.: Evolution of the chemical fingerprint of biomass burning organic aerosol during aging, Atmos. Chem. Phys., 18, 7607-7624, https://doi.org/10.5194/acp-18-7607-2018, 2018.

Bruns, E., El Haddad, I., Slowik, J., Kilic, D., Klein, F., Baltensperger, U., and Prévôt, A. S. H.: Identification of significant precursor gases of secondary organic aerosols from residential wood combustion, Sci. Rep., 6, 27881, https://doi.org/10.1038/srep27881, 2016.

Bozzetti, C., Daellenbach, K. R., Hueglin, C., Fermo, P., Sciare, J., Kasper-Giebl, A., Mazar, Y., Abbaszade, G., El Kazzi, M., Gonzalez, R., Shuster-Meiseles, T., Flasch, M., Wolf, R., Krepelova, A., Canonaco, F., Schnelle-Kreis, J., Slowik, J. G., Zimmermann, R., Rudich, Y., Baltensperger, U., El Haddad, I., and Prevot, A. S.: Size-resolved identification, characterization, and quantification of primary biological organic aerosol at a european rural site, Environ. Sci. Technol., 50, 3425-3434, https://doi.org/10.1021/acs.est.5b05960, 2016.

Bozzetti, C., Sosedova, Y., Xiao, M., Daellenbach, K. R., Ulevicius, V., Dudoitis, V., Mordas, G., Byčenkienè, S., Plauškaitè, K., Vlachou, A., Golly, B., Chazeau, B., Besombes, J.-L., Baltensperger, U., Jaffrezo, J.-L., Slowik, J. G., El Haddad, I., and Prévôt, A. S. H.: Argon offline-AMS source apportionment of organic aerosol over yearly cycles for an urban, rural, and marine site in northern Europe, Atmos. Chem. Phys., 17, 117-141, https://doi.org/10.5194/acp-17-117-2017, 2017. 
Canonaco, F., Crippa, M., Slowik, J. G., Baltensperger, U., and Prévôt, A. S. H.: SoFi, an IGOR-based interface for the efficient use of the generalized multilinear engine (ME2) for the source apportionment: ME-2 application to aerosol mass spectrometer data, Atmos. Meas. Tech., 6, 3649-3661, https://doi.org/10.5194/amt-6-3649-2013, 2013.

Canonaco, F., Slowik, J. G., Baltensperger, U., and Prévôt, A. S. H.: Seasonal differences in oxygenated organic aerosol composition: implications for emissions sources and factor analysis, Atmos. Chem. Phys., 15, 6993-7002, https://doi.org/10.5194/acp15-6993-2015, 2015.

Cavalli, F., Viana, M., Yttri, K. E., Genberg, J., and Putaud, J. P.: Toward a standardised thermal-optical protocol for measuring atmospheric organic and elemental carbon: the EUSAAR protocol, Atmos. Meas. Tech., 3, 79-89, https://doi.org/10.5194/amt-3-792010, 2010.

Claeys, M., Szmigielski, R., Kourtchev, I., Van der Veken, P., Vermeylen, R., Maenhaut, W., Jaoui, M., Kleindienst, T. E., Lewandowski, M., Offenberg, J. H., and Edney, E. O.: Hydroxydicarboxylic acids: markers for secondary organic aerosol from the photooxidation of $\alpha$-pinene, Environ. Sci. Technol., 41, 1628-1634, https://doi.org/10.1021/es0620181, 2007.

Crippa, M., Canonaco, F., Slowik, J. G., El Haddad, I., DeCarlo, P. F., Mohr, C., Heringa, M. F., Chirico, R., Marchand, N., Temime-Roussel, B., Abidi, E., Poulain, L., Wiedensohler, A., Baltensperger, U., and Prévôt, A. S. H.: Primary and secondary organic aerosol origin by combined gas-particle phase source apportionment, Atmos. Chem. Phys., 13, 8411-8426, https://doi.org/10.5194/acp-13-8411-2013, 2013a.

Crippa, M., DeCarlo, P. F., Slowik, J. G., Mohr, C., Heringa, M. F., Chirico, R., Poulain, L., Freutel, F., Sciare, J., Cozic, J., Di Marco, C. F., Elsasser, M., Nicolas, J. B., Marchand, N., Abidi, E., Wiedensohler, A., Drewnick, F., Schneider, J., Borrmann, S., Nemitz, E., Zimmermann, R., Jaffrezo, J. L., Prévôt, A. S. H., and Baltensperger, U.: Wintertime aerosol chemical composition and source apportionment of the organic fraction in the metropolitan area of Paris, Atmos. Chem. Phys., 13, 961-981, https://doi.org/10.5194/acp-13-961-2013, 2013b.

Crippa, M., Canonaco, F., Lanz, V. A., Äijälä, M., Allan, J. D., Carbone, S., Capes, G., Ceburnis, D., Dall'Osto, M., Day, D. A., DeCarlo, P. F., Ehn, M., Eriksson, A., Freney, E., Hildebrandt Ruiz, L., Hillamo, R., Jimenez, J. L., Junninen, H., KiendlerScharr, A., Kortelainen, A. M., Kulmala, M., Laaksonen, A., Mensah, A. A., Mohr, C., Nemitz, E., O’Dowd, C., Ovadnevaite, J., Pandis, S. N., Petäjä, T., Poulain, L., Saarikoski, S., Sellegri, K., Swietlicki, E., Tiitta, P., Worsnop, D. R., Baltensperger, U., and Prévôt, A. S. H.: Organic aerosol components derived from 25 AMS data sets across Europe using a consistent ME-2 based source apportionment approach, Atmos. Chem. Phys., 14, 61596176, https://doi.org/10.5194/acp-14-6159-2014, 2014.

Cuccia, E., Massabo, D., Ariola, V., Bove, M. C., Fermo, P., Piazzalunga, A., and Prati, P.: Size-resolved comprehensive characterization of airborne particulate matter, Atmos. Environ., 67, 14-26, https://doi.org/10.1016/j.atmosenv.2012.10.045, 2013.

Daellenbach, K. R., Bozzetti, C., Křepelová, A., Canonaco, F., Wolf, R., Zotter, P., Fermo, P., Crippa, M., Slowik, J. G., Sosedova, Y., Zhang, Y., Huang, R. J., Poulain, L., Szidat, S., Baltensperger, U., El Haddad, I., and Prévôt, A. S. H.: Characterization and source apportionment of organic aerosol using of- fline aerosol mass spectrometry, Atmos. Meas. Tech., 9, 23-39, https://doi.org/10.5194/amt-9-23-2016, 2016.

Daellenbach, K. R., Stefenelli, G., Bozzetti, C., Vlachou, A., Fermo, P., Gonzalez, R., Piazzalunga, A., Colombi, C., Canonaco, F., Hueglin, C., Kasper-Giebl, A., Jaffrezo, J.-L., Bianchi, F., Slowik, J. G., Baltensperger, U., El-Haddad, I., and Prévôt, A. S. H.: Long-term chemical analysis and organic aerosol source apportionment at nine sites in central Europe: source identification and uncertainty assessment, Atmos. Chem. Phys., 17, 13265-13282, https://doi.org/10.5194/acp-17-132652017, 2017.

DeCarlo, P. F., Kimmel, J. R., Trimborn, A., Northway, M. J., Jayne, J. T., Aiken, A. C., Gonin, M., Fuhrer, K., Horvath, T., Docherty, K. S., Worsnop, D. R., and Jimenez, J. L.: Field-deployable, high-resolution, time-of-flight aerosol mass spectrometer, Anal. Chem., 78, 8281-8289, https://doi.org/10.1021/Ac061249n, 2006.

DeCarlo, P. F., Dunlea, E. J., Kimmel, J. R., Aiken, A. C., Sueper, D., Crounse, J., Wennberg, P. O., Emmons, L., Shinozuka, Y., Clarke, A., Zhou, J., Tomlinson, J., Collins, D. R., Knapp, D., Weinheimer, A. J., Montzka, D. D., Campos, T., and Jimenez, J. L.: Fast airborne aerosol size and chemistry measurements above Mexico City and Central Mexico during the MILAGRO campaign, Atmos. Chem. Phys., 8, 4027-4048, https://doi.org/10.5194/acp-8-4027-2008, 2008.

Després, V., Huffman, J. A., Burrows, S. M., Hoose, C., Safatov, A., Buryak, G., Fröhlich-Nowoisky, J., Elbert, W., Andreae, M., Pöschl, U., and Jaenicke, R.: Primary biological aerosol particles in the atmosphere: a review, Tellus B, 64, 15598, https://doi.org/10.3402/tellusb.v64i0.15598, 2012.

Elser, M., Huang, R.-J., Wolf, R., Slowik, J. G., Wang, Q., Canonaco, F., Li, G., Bozzetti, C., Daellenbach, K. R., Huang, Y., Zhang, R., Li, Z., Cao, J., Baltensperger, U., El-Haddad, I., and Prévôt, A. S. H.: New insights into $\mathrm{PM}_{2.5}$ chemical composition and sources in two major cities in China during extreme haze events using aerosol mass spectrometry, Atmos. Chem. Phys., 16, 3207-3225, https://doi.org/10.5194/acp-16-3207-2016, 2016.

Fröhlich, R., Cubison, M. J., Slowik, J. G., Bukowiecki, N., Prévôt, A. S. H., Baltensperger, U., Schneider, J., Kimmel, J. R., Gonin, M., Rohner, U., Worsnop, D. R., and Jayne, J. T.: The ToF-ACSM: a portable aerosol chemical speciation monitor with TOFMS detection, Atmos. Meas. Tech., 6, 3225-3241, https://doi.org/10.5194/amt-6-3225-2013, 2013.

Fröhlich, R., Crenn, V., Setyan, A., Belis, C. A., Canonaco, F., Favez, O., Riffault, V., Slowik, J. G., Aas, W., Aijälä, M., Alastuey, A., Artiñano, B., Bonnaire, N., Bozzetti, C., Bressi, M., Carbone, C., Coz, E., Croteau, P. L., Cubison, M. J., EsserGietl, J. K., Green, D. C., Gros, V., Heikkinen, L., Herrmann, H., Jayne, J. T., Lunder, C. R., Minguillón, M. C., Močnik, G., O’Dowd, C. D., Ovadnevaite, J., Petralia, E., Poulain, L., Priestman, M., Ripoll, A., Sarda-Estève, R., Wiedensohler, A., Baltensperger, U., Sciare, J., and Prévôt, A. S. H.: ACTRIS ACSM intercomparison - Part 2: Intercomparison of ME-2 organic source apportionment results from 15 individual, co-located aerosol mass spectrometers, Atmos. Meas. Tech., 8, 2555-2576, https://doi.org/10.5194/amt-8-2555-2015, 2015.

Heal, M. R., Kumar, P., and Harrison, R. M.: Particles, air quality, policy and health, Chem. Soc. Rev., 41, 6606-6630, 2012. 
Hu, W. W., Hu, M., Yuan, B., Jimenez, J. L., Tang, Q., Peng, J. F., Hu, W., Shao, M., Wang, M., Zeng, L. M., Wu, Y. S., Gong, Z. H., Huang, X. F., and He, L. Y.: Insights on organic aerosol aging and the influence of coal combustion at a regional receptor site of central eastern China, Atmos. Chem. Phys., 13, 10095-10112, https://doi.org/10.5194/acp-13-10095-2013, 2013.

Jaenicke, R.: Abundance of cellular material and proteins in the atmosphere, Science, 308, 73 pp., https://doi.org/10.1126/science.1106335, 2005.

Jimenez, J. L., Jayne, J. T., Shi, Q., Kolb, C. E., Worsnop, D. R., Yourshaw, I., Seinfeld, J. H., Flagan, R. C., Zhang, X. F., Smith, K. A., Morris, J. W., and Davidovits, P.: Ambient aerosol sampling using the Aerodyne Aerosol Mass Spectrometer, J. Geophys. Res.-Atmos., 108, 8425, https://doi.org/10.1029/2001jd001213, 2003.

Jimenez, J. L., Canagaratna, M. R., Donahue, N. M., Prevot, A. S. H., Zhang, Q., Kroll, J. H., DeCarlo, P. F., Allan, J. D., Coe, H., Ng, N. L., Aiken, A. C., Docherty, K. S., Ulbrich, I. M., Grieshop, A. P., Robinson, A. L., Duplissy, J., Smith, J. D., Wilson, K. R., Lanz, V. A., Hueglin, C., Sun, Y. L., Tian, J., Laaksonen, A., Raatikainen, T., Rautiainen, J., Vaattovaara, P., Ehn, M., Kulmala, M., Tomlinson, J. M., Collins, D. R., Cubison, M. J., Dunlea, E. J., Huffman, J. A., Onasch, T. B., Alfarra, M. R., Williams, P. I., Bower, K., Kondo, Y., Schneider, J., Drewnick, F., Borrmann, S., Weimer, S., Demerjian, K., Salcedo, D., Cottrell, L., Griffin, R., Takami, A., Miyoshi, T., Hatakeyama, S., Shimono, A., Sun, J. Y., Zhang, Y. M., Dzepina, K., Kimmel, J. R., Sueper, D., Jayne, J. T., Herndon, S. C., Trimborn, A. M., Williams, L. R., Wood, E. C., Middlebrook, A. M., Kolb, C. E., Baltensperger, U., and Worsnop, D. R.: Evolution of organic aerosols in the atmosphere, Science, 326, 1525-1529, https://doi.org/10.1126/science.1180353, 2009.

Kelly, F. J. and Fussell, J. C.: Size, source and chemical composition as determinants of toxicity attributable to ambient particulate matter, Atmos. Environ., 60, 504-526, https://doi.org/10.1016/j.atmosenv.2012.06.039, 2012.

Lanz, V. A., Alfarra, M. R., Baltensperger, U., Buchmann, B., Hueglin, C., and Prévôt, A. S. H.: Source apportionment of submicron organic aerosols at an urban site by factor analytical modelling of aerosol mass spectra, Atmos. Chem. Phys., 7, 15031522, https://doi.org/10.5194/acp-7-1503-2007, 2007.

Lin, P., Aiona, P. K., Li, Y., Shiraiwa, M., Laskin, J., Nizkorodov, S. A., and Laskin, A.: Molecular characterization of brown carbon in biomass burning aerosol particles, Environ. Sci. Technol., 50, 11815-11824, https://doi.org/10.1021/acs.est.6b03024, 2016.

Lopez-Hilfiker, F. D., Pospisilova, V., Huang, W., Kalberer, M., Mohr, C., Stefenelli, G., Thornton, J. A., Baltensperger, U., Prevot, A. S. H., and Slowik, J. G.: An extractive electrospray ionization time-of-flight mass spectrometer (EESI-TOF) for online measurement of atmospheric aerosol particles, Atmos. Meas. Tech., 12, 4867-4886, https://doi.org/10.5194/amt12-4867-2019, 2019.

Ng, N. L., Chhabra, P. S., Chan, A. W. H., Surratt, J. D., Kroll, J. H., Kwan, A. J., McCabe, D. C., Wennberg, P. O., Sorooshian, A., Murphy, S. M., Dalleska, N. F., Flagan, R. C., and Seinfeld, J. H.: Effect of $\mathrm{NO}_{x}$ level on secondary organic aerosol (SOA) formation from the photooxidation of terpenes, Atmos. Chem. Phys., 7, 5159-5174, https://doi.org/10.5194/acp-7-5159-2007, 2007.
Paatero, P. and Tapper, U.: Positive matrix factorization: A non-negative factor model with optimal utilization of error estimates of data values, Environmetrics, 5, 111-126, https://doi.org/10.1002/env.3170050203, 1994.

Piazzalunga, A., Bernardoni, V., Fermo, P., and Vecchi, R.: Optimisation of analytical procedures for the quantification of ionic and carbonaceous fractions in the atmospheric aerosol and applications to ambient sample, Anal. Bioanaly. Chem., 405, 11231132, https://doi.org/10.1007/s00216-012-6433-5, 2013.

Pieber, S. M., El Haddad, I., Slowik, J. G., Canagaratna, M. R., Jayne, J. T., Platt, S. M., Bozzetti, C., Daellenbach, K. R., Frohlich, R., Vlachou, A., Klein, F., Dommen, J., Miljevic, B., Jimenez, J. L., Worsnop, D. R., Baltensperger, U., and Prevot, A. S.: Inorganic Salt Interference on $\mathrm{CO}_{2}^{+}$in Aerodyne AMS and ACSM Organic Aerosol Composition Studies, Environ. Sci. Technol., 50, 10494-10503, https://doi.org/10.1021/acs.est.6b01035, 2016.

Pospisilova, V., Lopez-Hilfiker, F. D., Bell, D. M., El Haddad, I., Mohr, C., Huang, W., Heikkinen, L., Xiao, M., Dommen, J., Prevot, A. S. H., and Baltensperger, U.: On the fate of oxygenated organic molecules in atmospheric aerosol particles, Sci. Adv., 6, eaax8922, https://doi.org/10.1126/sciadv.aax8922, 2020.

Qi, L., Chen, M., Stefenelli, G., Pospisilova, V., Tong, Y., Bertrand, A., Hueglin, C., Ge, X., Baltensperger, U., Prévôt, A. S. H., and Slowik, J. G.: Organic aerosol source apportionment in Zurich using an extractive electrospray ionization time-of-flight mass spectrometer (EESI-TOF-MS) - Part 2: Biomass burning influences in winter, Atmos. Chem. Phys., 19, 8037-8062, https://doi.org/10.5194/acp-19-8037-2019, 2019.

Qi, L., Vogel, A. L., Esmaeilirad, S., Cao, L., Zheng, J., Jaffrezo, J.-L., Fermo, P., Kasper-Giebl, A., Daellenbach, K. R., Chen, M., Ge, X., Baltensperger, U., Prévôt, A. S. H., and Slowik, J. G.: A 1-year characterization of organic aerosol composition and sources using an extractive electrospray ionization time-of-flight mass spectrometer (EESI-TOF), Zenodo, https://doi.org/10.5281/zenodo.3930871, 2020.

Sánchez-Ochoa, A., Kasper-Giebl, A., Puxbaum, H., Gelencser, A., Legrand, M., and Pio, C.: Concentration of atmospheric cellulose: A proxy for plant debris across a westeast transect over Europe, J. Geophys. Res., 112, D23S08, https://doi.org/10.1029/2006jd008180, 2007.

Schilling, M. R., Heginbotham, A., van Keulen, H., and Szelewski, M.: Beyond the basics: A systematic approach for comprehensive analysis of organic materials in Asian lacquers, Stud. Conserv., 61, 3-27, https://doi.org/10.1080/00393630.2016.1230978, 2016.

Stefenelli, G., Pospisilova, V., Lopez-Hilfiker, F. D., Daellenbach, K. R., Hüglin, C., Tong, Y., Baltensperger, U., Prévôt, A. S. H., and Slowik, J. G.: Organic aerosol source apportionment in Zurich using an extractive electrospray ionization time-offlight mass spectrometer (EESI-TOF-MS) - Part 1: Biogenic influences and day-night chemistry in summer, Atmos. Chem. Phys., 19, 14825-14848, https://doi.org/10.5194/acp-19-148252019, 2019.

Sun, Y. L., Wang, Z. F., Fu, P. Q., Yang, T., Jiang, Q., Dong, H. B., Li, J., and Jia, J. J.: Aerosol composition, sources and processes during wintertime in Beijing, China, Atmos. Chem. Phys., 13, 4577-4592, https://doi.org/10.5194/acp-13-4577-2013, 2013. 
Takahama, S., Johnson, A., Guzman Morales, J., Russell, L. M., Duran, R., Rodriguez, G., Zheng, J., Zhang, R., ToomSauntry, D., and Leaitch, W. R.: Submicron organic aerosol in Tijuana, Mexico, from local and Southern California sources during the CalMex campaign, Atmos. Environ., 70, 500-512, https://doi.org/10.1016/j.atmosenv.2012.07.057, 2013.

Tervahattu, H., Juhanoja, J., Vaida, V., Tuck, A. F., Niemi, J. V., Kupiainen, K., Kulmala, M., and Vehkamäki, H.: Fatty acids on continental sulfate aerosol particles, J. Geophys. Res.-Atmos., 110, D06207, https://doi.org/10.1029/2004jd005400, 2005.

Ulbrich, I. M., Canagaratna, M. R., Zhang, Q., Worsnop, D. R., and Jimenez, J. L.: Interpretation of organic components from Positive Matrix Factorization of aerosol mass spectrometric data, Atmos. Chem. Phys., 9, 2891-2918, https://doi.org/10.5194/acp-92891-2009, 2009.

Vlachou, A., Daellenbach, K. R., Bozzetti, C., Chazeau, B., Salazar, G. A., Szidat, S., Jaffrezo, J.-L., Hueglin, C., Baltensperger, U., Haddad, I. E., and Prévôt, A. S. H.: Advanced source apportionment of carbonaceous aerosols by coupling offline AMS and radiocarbon size-segregated measurements over a nearly 2-year period, Atmos. Chem. Phys., 18, 6187-6206, https://doi.org/10.5194/acp-18-6187-2018, 2018.

Zhang, H., Yee, L. D., Lee, B. H., Curtis, M. P., Worton, D. R., Isaacman-VanWertz, G., Offenberg, J. H., Lewandowski, M., Kleindienst, T. E., Beaver, M. R., Holder, A. L., Lonneman, W. A., Docherty, K. S., Jaoui, M., Pye, H. O. T., Hu, W., Day, D. A., Campuzano-Jost, P., Jimenez, J. L., Guo, H., Weber, R. J., de Gouw, J., Koss, A. R., Edgerton, E. S., Brune, W., Mohr, C., Lopez-Hilfiker, F. D., Lutz, A., Kreisberg, N. M., Spielman, S. R., Hering, S. V., Wilson, K. R., Thornton, J. A., and Goldstein, A. H.: Monoterpenes are the largest source of summertime organic aerosol in the southeastern United States, P. Natl. Acad. Sci. USA, 115, 2038-2043, https://doi.org/10.1073/pnas.1717513115, 2018.
Zhang, Q., Jimenez, J., Canagaratna, M., Ulbrich, I., Ng, N., Worsnop, D., and Sun, Y.: Understanding atmospheric organic aerosols via factor analysis of aerosol mass spectrometry: a review, Anal. Bioanal. Chem., 401, 3045-3067, https://doi.org/10.1007/s00216-011-5355-y, 2011.

Zotter, P., Ciobanu, V. G., Zhang, Y. L., El-Haddad, I., Macchia, M., Daellenbach, K. R., Salazar, G. A., Huang, R.-J., Wacker, L., Hueglin, C., Piazzalunga, A., Fermo, P., Schwikowski, M., Baltensperger, U., Szidat, S., and Prévôt, A. S. H.: Radiocarbon analysis of elemental and organic carbon in Switzerland during winter-smog episodes from 2008 to 2012 - Part 1: Source apportionment and spatial variability, Atmos. Chem. Phys., 14, 1355113570, https://doi.org/10.5194/acp-14-13551-2014, 2014. 